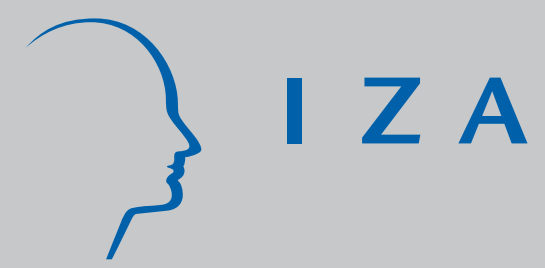

IZA DP No. 4874

Selection Policy and Immigrants' Remittance Behaviour

Stephane Mahuteau

Matloob Piracha

Massimiliano Tani

April 2010

Forschungsinstitut zur Zukunft der Arbeit Institute for the Study of Labor 


\title{
Selection Policy and Immigrants' Remittance Behaviour
}

\author{
Stephane Mahuteau \\ Macquarie University \\ Matloob Piracha \\ University of Kent \\ and IZA \\ Massimiliano Tani \\ Macquarie University \\ and IZA
}

Discussion Paper No. 4874

April 2010

IZA

P.O. Box 7240

53072 Bonn

Germany

Phone: +49-228-3894-0

Fax: +49-228-3894-180

E-mail: iza@iza.org

Any opinions expressed here are those of the author(s) and not those of IZA. Research published in this series may include views on policy, but the institute itself takes no institutional policy positions.

The Institute for the Study of Labor (IZA) in Bonn is a local and virtual international research center and a place of communication between science, politics and business. IZA is an independent nonprofit organization supported by Deutsche Post Foundation. The center is associated with the University of Bonn and offers a stimulating research environment through its international network, workshops and conferences, data service, project support, research visits and doctoral program. IZA engages in (i) original and internationally competitive research in all fields of labor economics, (ii) development of policy concepts, and (iii) dissemination of research results and concepts to the interested public.

IZA Discussion Papers often represent preliminary work and are circulated to encourage discussion. Citation of such a paper should account for its provisional character. A revised version may be available directly from the author. 
IZA Discussion Paper No. 4874

April 2010

\section{ABSTRACT}

\section{Selection Policy and Immigrants' Remittance Behaviour ${ }^{\star}$}

This paper analyses the impact of a change in Australia's immigration policy, introduced in the mid-1990s, on migrants' remittance behaviour. More precisely, we compare the remittance behaviour of two cohorts who entered Australia before and after the policy change, which consists of stricter entry requirements. The results indicate that those who entered under more stringent conditions - the second cohort - have a lower probability to remit but, if remitting, they tend to remit, on average, a higher amount than those in the first cohort. We also find significant time and region effects. Contrary to some existing evidence, time spent in Australia positively affects the probability to remit while in terms of regional effects, South Asians remit the highest amount. We discuss intuitions for the results in the paper.

JEL Classification: F22, F24, J61

Keywords: remittances, immigration, selection policy

Corresponding author:

Matloob Piracha

School of Economics

University of Kent

Canterbury, Kent CT2 7NP

United Kingdom

E-mail: M.E.Piracha@kent.ac.uk

\footnotetext{
* We would like to thank Jagjit Chadha and lain Fraser for helpful comments on an earlier version of the paper. Part of the paper was completed when the second author was visiting Faculty of Business and Economics at the Macquarie University, whose financial support and hospitality is gratefully acknowledged.
} 


\section{Introduction}

International migration from developing countries is often linked to expectations of mutual gains for the migrants and their home and host countries. Migrants benefit if the net return to their skills is higher in the host country than in their home country. The immigration of workers allows receiving countries to fill domestic labour market shortages and provide host country employers the private benefit to meet productive capacity without large hikes in wages. This is particularly so when domestic labour shortages are skill-specific and when migration policy is tuned to select such skills to grant entry into the country, as is the case in Australia.

Recent literature has highlighted the importance of remittances as 'compensation' for a potential brain drain from the sending countries. The aggregate value of remittances is larger than those of common commodities traded, and most sending countries appear to receive substantial inflows (e.g. Philippines, Mexico, the Pacific islands, North Africa). However, it has also been highlighted that more skilled migrants tend to remit less than those with lower levels of education, leading to the implication that the brain drain is not properly compensated for when more educated leave the country.

Understanding the conditions that affect the remittance pattern of migrants is important to contextualise the net benefits of migration. For instance, one of the benefits from the sending country's perspective is that remittances help the recipient family to fund consumption as well as invest proportion of the transferred funds to start a business, especially when credit markets are not properly developed. From the host country perspective, the economic benefits of migration include meeting the spare capacity in the labour market; impact on the fiscal policy in terms of, for instance, tax receipt from the new arrivals, especially in the presence of declining native population.

One of the best ways to achieve these objectives is through a proper economic (and of course social as well) assimilation of immigrants in the host country. These aspects are usually fulfilled by relatively higher skilled migrants as they tend to migrate with their immediate families and consequently are less likely to remit and save more in the host country, thus in an economic sense behaving more like natives. Therefore, migration admission policy not only has a direct impact on skill composition of new immigrants but also an indirect impact on their assimilation process, particularly on their saving/remittance behaviour. The reason to single out the remittance behaviour only is that, as discussed above, it has a direct impact on the sending countries, not only on family left behind but also from the point of view of compensation for the brain drain from the sending countries. 
Existing work on migrant remittances and their effect on the economies of developing nations have rarely focused on the conditions that affect migrants' remittance pattern. These typically analyse the underlying motivations to remit. For instance, in the presence of uncertainty about their legal status and/or labour market conditions migrants could potentially remit more because of the insurance motive rather than, say, the altruistic motive (see Amuedo-Dorantes and Pozo, 2004; Piracha and Zhu, 2007). These motivations could indeed be affected by the change in conditions in the host country, particularly a change in the immigration policy as that has an implication for immigrants' legal status. The main argument here is that the net benefits of migration are subject to the policy shift in both sending and receiving countries.

However, there is limited research examining the effect of a change of policy on remittance behaviour. We contribute to the scant literature by looking at the impact of a change in Australia's immigrant admission policies, in mid-1990s, on migrants' remittance flows. ${ }^{1}$.. We compare the remittance behaviour of two cohorts who entered Australia at different points in time. The first cohort entered Australia between 1993 and 1995, just before the policy change while the second one entered in 1999-2000, after the policy change. The main difference between the two cohorts is the change in the entry requirements. Entry conditions after 1996 were more stringent in terms of skills (education and work experience) and knowledge of English. Post-1996 immigrants had neither income support for the first two years after migration, nor subsidies to attend English classes. As a result, those entering under work visa category in 1999 were more educated and had better English language skills than the previous cohort. We use this policy change to quantify the impact on immigrants' remittance behaviour. In particular, we estimate the effect of the policy change on the probability and the level of remittances.

Recent literature that has analysed the economic effect of the change in Australian immigration policy using the LSIA has almost exclusively concentrated on the labour market performance of immigrants. For instance, Cobb-Clark (2000, 2004) highlights that immigrants selected under the new immigration regime fare better in the labour market than those to whom the policy change does not apply (family reunification and refugees). Chiswick and Miller (2006) arrive to a similar conclusion attributing the effect of the positive labour market outcome to a better selection on the knowledge of the host country's language

\footnotetext{
${ }^{1}$ Although this change coincides with a change in the political party governing the country (from labour to conservative), we restrict our analysis to the economic effect of the change in migration policy. It should also be noted that there was no other policy change, sue to the change in the government, that specifically affected the immigrants.
} 
(English). ${ }^{2}$ However, none of these papers study the impact of policy change on immigrants' remittances flows.

Our results show that the policy change had an impact on both the probability and the level of remittances. The results indicate that those who entered under more stringent conditions - the second cohort - have a lower probability to remit but, if remitting, tend to remit, on average, a higher amount than those in the first cohort. We also find significant time and region effects. Contrary to some existing evidence, time spent in Australia positively affects the probability to remit while in terms of regional effects, South Asians remit the highest amount.

The rest of the paper is organised as follows. Discussion on the background on immigration policy in Australia is presented in Section 2. Description of the data used appears in Section 3 while Section 4 discusses the empirical methodology. The estimation results are analysed in Section 5. Concluding remarks appear in the last section.

\section{Background of Immigration Policy}

To understand the development of policies leading to the changes in the mid-1990s, one needs to put some context to Australia’s immigration policy. In 1972 Australia formally ended a migration policy based on ethnicity ('white Australia policy'), replacing it with a focus on economic conditions to a limited number of workers in occupations where there was unmet demand. ${ }^{3}$ Eliminating racial discrimination from immigration selection resulted in increasing numbers of applicants and refugees from non-European countries and consequently higher stocks of immigrants with non-English speaking background (NESB). As an example Australia has taken refugees from conflicts in Chile (1973), Northern Cyprus (1974), Lebanon (1976-1983), Vietnam (1976-1982), Thailand (1976), East Timor (1977), Sri Lanka and El Salvador (1983) and the former Yugoslavia (1994).

Until the policy change introduced in 1996 and analysed in this paper, two major trends have characterized immigration policy in Australia. First, the development of a systematic approach to immigration selection based on current labour market conditions. This

\footnotetext{
2 There is a related literature using Canadian and US data. Jasso and Rosenzweig (1995) and Green (1995; 1999) respectively show that those who entered on the basis of skills are more likely to enter skilled occupations in the United States and Canada. Entry class is also related to immigrant earnings. Employment-based immigrants to the United States have higher initial earnings (Sorensen, et al., 1992; Duleep and Regets, 1996), while the fraction of individuals entering Canada as independent migrants is positively related to average entry wages (Wright and Maxim, 1993).

${ }^{3}$ This was in addition to the priority given to family reunification.
} 
took place during the late 1970s and throughout the 1980s with the introduction of the Numerical Multifactor Assessment System (NUMAS) during 1979-1982, which selected immigrants on the basis of family ties, occupational and language skills, and the points test (since 1988) which was used to set annually a minimum pass mark to be eligible for migration based on the skill level (qualifications and work experience), age and English language proficiency. Points could be gained if the applicant was qualified to work in one of the occupations listed in a Priority Occupation List, which summarises employers' views and recruitment difficulties. Pre-migration English-language testing for particular occupations (chosen annually) was also introduced in 1989, first in the medical and nursing professions and then extending to 114 professions between 1991 and 1993 (Hawthorne, 1997; 2006), with points provided for both speaking and writing language abilities. Since 1988 the migration program is divided into three streams, 'family reunification', 'skill', and 'humanitarian', with the 'skill' stream contributing about one third of all migrants to Australia until 1995-96.

The second trend has been the development of policies to favour the settlement and participation of migrants, especially if from NESB, to Australia's economic activity. This was accompanied by the introduction of instruments, including ad hoc data collections, to analyse their economic outcomes. Even with higher skill levels than comparable natives or migrants with an English-speaking background (Watson, 1996), NESB immigrants were characterized by substantially lower economic outcomes. To overcome a linguistic disadvantage, Australia had put in place a publicly funded system to provide new adult NESB immigrants with free language courses (as well as locally-funded technical training). Immigrants were paid to attend these courses, which lasted between one and six months and led them to attain a level of language ability that was adequate for employment. By 1990, Australia’s Adult Migrant English Program (AMEP) “was the largest government-funded English teaching program for migrants worldwide, catering to over 70,000 immigrants per year including large number of unemployed professionals” (Hawthorne, 2006 p.675-676). The government actively pursued the private sector to adopt Equal Opportunity principles towards NESB as well as facilitated to ease the admission of 'professionals' from NESB (managed by professional associations) with the funding of specialist labour market programs designed to prepare NESB professionals for mandatory entry exams in a range of professions like medicine, engineering and nursing. 
In 1996 a newly elected government introduced a number of significant changes to the migration policy, affecting the skill and family reunification but not the humanitarian streams. This new policy:

(1) Abolished the social security benefit to new immigrants in the first two years after their arrival, as well as access to the Adult Migrant English Program (whose costs were now to be met by the immigrant) and labour market programs (whose costs were to be repaid after securing work);

(2) Allocated the highest points weighting to employability factors, namely occupational skills, education, age, and English language ability. Age-related points for applicants over the age of 45 were abolished while bonus points were awarded to those with relevant Australian or international professional work experience, a job offer, a spouse meeting the skill application criteria, an Australian sponsor who had to provide a guarantee, and carrying A\$100,000 or more in capital. By 2001 most migrants to Australia were in the skill stream;

(3) Introduced additional points for occupations in demand in addition to degree-level specific (as opposed to generic) qualifications, and bonus points for qualifications obtained recently in Australia;

(4) Pre-migration qualification screening was effectively outsourced to professional bodies, who could now disqualify NESB applicants from eligibility for skill migration.

\section{The Longitudinal Survey of Immigrants to Australia}

The Longitudinal Survey of Immigrants in Australia (LSIA) was commissioned in the early 1990s to fulfil the need to have better information on the settlement of new migrants than those available through censuses. The LSIA survey is based on a representative sample of $5 \%$ of migrants/refugees from successive cohorts of migrants. The data was primarily designed to study the process of immigrant settlement. The LSIA comprises three surveys over a period of almost 10 years: LSIA1 was conducted in 1993-1995 and contains three waves, with immigrants interviewed at 6 month intervals. LSIA2 has two waves, with immigrants interviewed 6 months after arrival and then 18 months after arrival (June 1999, June 2000). LSIA3 has only one wave; with interviews conducted in 2003-2004. ${ }^{4}$ The LSIA

\footnotetext{
${ }^{4}$ The new policy also reduced funding for the LSIA data collection.
} 
contains more than 300 questions about the decision to migrate and the subsequent experience after arrival in Australia.

The LSIA data oversamples some groups of individuals based notably on visa categories. The refugee category is overrepresented in the samples but weights are available to recover population statistics and estimates.

There are more than 300 questions about the settlement process in each wave of the survey. It is a detailed data set which is particularly useful to disentangle the impact of policy change in Australia. Questions were asked both to the primary applicants (aged 15 and above) and the migrating-unit spouses. In addition to questions about personal and family characteristics, education and past employment status, it also asks questions about monetary transfers to the home country. LSIA3, which was carried out after the policy change, has not only one wave but a dramatically reduced number of questions as well. This makes it inappropriate to use in our analysis. Hence the estimation sample in this paper is restricted to LSIA1 and LSIA2. First wave of LSIA1 is based on 5192 primary applicants and 1838 migrating-unit spouses while a further 3124 primary applicants and 1094 migrating-unit spouses were included in wave 1 of LSIA2. ${ }^{5}$ Figures 1 and 2 present the comparison between and across the two cohorts for each wave of interviews.

Comparing migrants from cohort 1 and 2, we see that there is an increase in the business stream group, an increase in the independent stream group; a small decrease in family migrants and a fall in the humanitarian streams (see Table 1). Regional breakdown of migrants in LSIA 1 and LSIA 2 shows that the proportion in each cohort for the following groups of countries increased: Oceania, Middle East, North East Asia (which includes China and Hong Kong), South Asia and Africa (See Table 2)

In regards to the human capital characteristics of the migrants, the second cohort had in general better education levels than the first cohort. The comparison between cohorts presented in Table 3 shows that cohort 2 tends to have a higher educational qualifications, especially with higher university degrees at the time of arrival.

In terms of labour market outcome in Australia, Table 4 shows that wage employees are biggest group across the cohorts though the second cohort has a much bigger number in employment both in wave 1 (6 months after arrival) and wave 2 (18 months after arrival) than the first cohort. Moreover, unemployment number is lower for second cohort (about half of cohort 1 migrants' unemployment rate on arrival), not only in comparison between first

\footnotetext{
${ }^{5}$ Migrating unit is this context includes all members of the family migrating to Australia under the same visa application. The term spouses is used for husband/wife, civil partners, fiancé(e)s etc.
} 
waves of both cohorts but even between wave 1 of cohort 1 and wave 3 of cohort 2. The percentage of business owners is also larger in the second cohort with $5 \%$ of the immigrant population for cohort 2 compared to 3\% for cohort 1 on arrival. Regarding the percentage of students and those not in the labour force, cohort 1 and 2 are comparable on arrival.

Tables 5 to 8 provide summary statistics on migrants' remittance behaviour across cohorts. Table 5 shows that the percentage of migrants remitting is smaller in cohort 2 upon arrival with $4.2 \%$ remitting compared to $7.8 \%$ in cohort 1 . The statistics and estimations using the values of remittances are deflated and expressed in year 2000 AUD. It appears that the average remittances are also larger in cohort 1 upon arrival. By the second wave of interview, the difference between the two cohorts is no longer significant, with average remittances of about $\mathrm{A} \$ 350$.

Table 6 reports average remittances according to the time spent in Australia. Since there is no third wave of interview in cohort 2, we only have 17 observations for which the migrants have been in Australia for more than 24 months. The average remittance figure of A \$30 for these observations is therefore not informative. Table 6 gives qualitatively similar information than the previous one: cohort 1 migrants remit more on average upon arrival but cohort 2 migrants catch up within 12 months. We also observe more variability in the remittance levels for first cohort migrants. The average percentages and amounts given in these tables hide important discrepancies across countries of origin. For instance, the percentage of individuals remitting to Southern Europe decreases by $73 \%$ between cohort 1 and 2 and by 68\% and 63\% for migrants from the Middle East and North East Asia respectively. Migrants from Eastern Europe and South America or Africa experience only half of such a fall in the percentage remitting (Table 7). Looking across waves, it appears that the percentage of migrants from Southern and Eastern Europe, South Asia and Middle East who remit increases faster in cohort 1 compared to those from other regions. In cohort 2, we observe the highest increases for individuals from the Middle East, South America or Africa, Southern Europe and South East Asia and the increase across waves is more modest. The multivariate estimations will enable us to see whether such large discrepancies remain among regions of origin once we control for individual characteristics, notably in terms of labour market outcome and family structure. Finally, Table 8 shows that, compared to cohort 1, the amount of remittances also falls in cohort 2, for all nationalities. 


\section{Empirical Methodology}

The aim of the estimations is twofold. First, we highlight the factors determining both the probability and the level of remittances by the newly arrived migrants surveyed in the LSIA. Second, we investigate to what extent the change in immigration policies (tightening of the point system and restriction in welfare payments) affected this remittance behaviour. Since the policy change had two opposing effects - negatively affecting some migrants' disposable income by restricting access to welfare payments while positively affecting the selection of more employable individuals with higher earning capacities (Mahuteau \& Junankar, 2008) - the overall effect on immigrants' remittance behaviour is ex ante not clear. On the one hand, restrictions imposed in the new regime could possibly cause higher financial pressure and/or uncertainty which may have increased the incentives to remit, perhaps for insurance purposes, in case of a failure in the migration experience. On the other hand, however tightening of migrants' selection suggests that they are more likely to be better qualified and hence have a higher probability to find a job, resulting in a lower demand for insurance. At the same time, remittances are not solely motivated by the insurance motive but also by altruistic concerns for relatives and friends left behind. It is likely that the latter motive is positively correlated with migrants' level of remittances. With the exception of more immigrants from Africa, there are not marked differences in the geographic composition of immigrants between the two cohorts.

Looking at individuals' remittance behaviour is very much like investigating households' durable good consumption in the sense that, in the survey period, one encounters a large proportion of observations with zeros. Remittances equal to zero for a given observation can be given two interpretations. On the one hand, it can be a behavioural zero, that is, the individual actually decided not to send money back. It represents a conscious choice arising from the comparison between the utility of sending versus not sending remittances. On the other hand, it can be a random zero or potential positive (Moffat, 2005) where the migrant would have a preference for remitting but, for some reason related to personal circumstances at the time of the survey (ability to pay, etc) has not been able to do so. Therefore the distribution of remittances in our sample is censored. This situation is commonly observed in studies of labour supply (Blundell \& Meghir, 1986), durable good consumption models, loan default analysis (Moffat, 2005) or valuation of wildlife conservation (Shrestha et. al. 2006). The estimation technique used hinges on the treatment we choose to give to the zero observations and whether we take into account the behavioural zeros explicitly. 
The common way of dealing with censored dependent variables is to estimate a Tobit model including all observations of the dependent variable, including the zeros, and correcting for censoring. The drawback of this method is that one considers the decision to participate and the level of participation as stemming from the same probability mechanism; the same determinants affect the probability to remit and the level of remittances. This specification may be adapted in some circumstances where it is reasonable to consider the zero values as corner solutions. However, in the case of migrants' remitting behaviour, economic theory suggests that some determinants may affect the probability to remit in one direction but the expected level of remittances in the opposite direction. This distinction is important in this paper since we are interested in the effect of migration policy changes on immigrants overall behaviour to remit.

Extensions of the Tobit model imply two equations (estimated simultaneously or not). The advantage of these models is that common regressors of both equations may affect the participation decision differently than the level of remittances. Moreover, they allow us to condition the participation decision on a different set of regressors than that used to explain the amount remitted by individuals. Several alternatives are available depending on whether we treat all zeros as stemming from an individual's decision not to participate (two-part model, Generalized Tobit and Heckman two-step selection model) or interpret part of the non-remittances as coming from some random event that prevented the migrant from remitting despite being willing to do so (double hurdle model with and without dependence). In some studies whose focus is on the usage of a particular good (cigarettes, internet, etc) or on labour supply, the two decisions are usually clearly separated. One question records ownership of the good, e.g., whether individuals are smokers or whether they participate in the labour force while the second question delimits a survey period for which individuals are asked about their level of consumption, number of hours worked as well as other relevant information. In such studies one is likely to encounter individuals who answer the first question in the affirmative but who record no consumption of the good at all during the survey period or no hours worked, hence two types of zeros appear in the data. Double hurdle models are designed specifically to deal with these two types of zeros explicitly in the likelihood function while two-part models, Generalized Tobit and two-step selection models assume that once the first hurdle is overcome (participation) one should not observe any zeros. In this paper, the occurrence and level of remittances variables are constructed from the same question. Therefore we only observe one type of zeros; that of non-participation. Remittance behaviour is described as follows: 


$$
\begin{aligned}
& d_{i}^{*}=z_{i}^{\prime} \beta_{1}+\varepsilon_{i} \text { with } d_{i}=\left\{\begin{array}{l}
1 \text { if } d_{1}^{*}>0 \\
0 \text { if } d_{1}^{*} \leq 0
\end{array}\right. \\
& y_{i}^{*}=x_{i}^{\prime} \beta_{2}+v_{i} \text { with } y_{i}=\left\{\begin{array}{l}
y_{i}^{*} \text { if } d_{i}=1 \\
0 \text { if } d_{i}=0
\end{array}\right.
\end{aligned}
$$

where the first equation represents the participation decision (first hurdle), that is whether the migrant decides to remit or not. $d_{i}^{*}$ is a latent variable representing the difference in utility between remitting and not remitting which is not observable. The observable counterpart of this latent variable consists in the actual observation of whether the migrant sent some money or not. $z_{i}$ is a vector of migrants' characteristics expected to affect the decision to remit such as education, current socio-economic situation. $y_{i}^{*}$ is also a latent variable whose observable counterpart is the max between 0 and the level of remittances; $x_{i}$ is a vector of characteristics, which may include exactly the same regressors as those included in $z_{i}$ or not (the model is specified either way).

In the generalized Tobit (Heckman, 1978), we assume that the unobservables in both equations are distributed bivariate normal with correlation $\rho$ :

$$
\left(\begin{array}{l}
\varepsilon_{i} \\
v_{i}
\end{array}\right) \sim N\left(\left(\begin{array}{l}
0 \\
0
\end{array}\right) ;\left(\begin{array}{cc}
1 & \rho \sigma \\
\rho \sigma & \sigma^{2}
\end{array}\right)\right)
$$

The subsequent likelihood to be maximized with respect to the parameters of the model is defined as:

$$
L=\prod_{i=1}^{n}\left[\operatorname{Pr}\left(d_{i}^{*} \leq 0\right)\right]^{1-d_{i}}\left[f\left(y_{i}^{*} \mid d_{i}^{*}>0\right) \cdot \operatorname{Pr}\left(d_{i}^{*}>0\right)\right]^{d_{i}}
$$

However, Heckman (1979) shows that a two-step estimation of the model is more robust since it doesn't rely on a bivariate normal distribution of the unobservables, which, in the case of remittance observations is unlikely. In a Monte Carlo study, Flood and Gråsjö (2001) show the extent of the bias implied by maximum likelihood estimation of this selection Tobit.

The two step estimation of the model implies estimating the first hurdle by Probit from which one calculates the Mills ratio $\left(\phi\left(z_{i}^{\prime} \beta_{1}\right) / \Phi\left(z_{i}^{\prime} \beta_{1}\right)\right)$ to be used as a regressor in the 
second equation estimated by OLS. The idea is that migrants who choose to remit are a selfselected group and hence estimations of the level of remittances need to be corrected for the selection bias they contain. Therefore, the two step model leads to the following conditional expectation regarding the remittance levels:

$E\left(y_{i} \mid x_{i}, y_{i}^{*}>0\right)=x_{i}^{\prime} \beta_{2}+\rho \sigma \frac{\phi\left(z_{i}^{\prime} \beta_{1}\right)}{\Phi\left(z_{i}^{\prime} \beta_{1}\right)}$

where $\lambda\left(z_{i}^{\prime} \beta_{1}\right)=\frac{\phi\left(z_{i}^{\prime} \beta_{1}\right)}{\Phi\left(z_{i}^{\prime} \beta_{1}\right)}$ is the Inverse Mills' ratio correcting for selection. It is computed from the results obtained in the Probit which models individuals' participation. The unconditional expectation of the amount of remittance is then given by:

$$
E\left(y_{i}\right)=\operatorname{Pr}\left(y_{i}^{*}>0\right) \cdot E\left(y_{i} \mid x_{i}, y_{i}^{*}>0\right)=\operatorname{Pr}\left(y_{i}^{*}>0\right) \cdot\left(x_{i}^{\prime} \beta_{2}+\rho \sigma \frac{\phi\left(z_{i}^{\prime} \beta_{1}\right)}{\Phi\left(z_{i}^{\prime} \beta_{1}\right)}\right)
$$

This method has been under some criticism in the literature (e.g., Manning et al., 1987; Hay et al., 1987) and has been compared it to the two-part model, which here implies that the decision to remit would be independent from the choice of remittance levels itself. The critics argue that the inclusion of the Mills' ratio in the second equation would cause severe collinearity issues with the model, especially if the vectors $z$ and $x$ contain the exact same variables. Indeed, it is sufficient that the first step of the estimation be non-linear (Probit) to be able to identify the parameters in both equations when the two vectors contain the same variables. Using Monte Carlo studies the critics argue that even when the true model is the two-step, the two-part model would perform best among the two. However, Leung and Yu (2000) resolve this controversy by providing further Monte Carlo studies highlighting the merits of the two-step method but also emphasizing the issue of collinearity in this type of model. They show that one can use a t-test to choose among the two models so long as there is no collinearity issue in the two-step. In order to avoid collinearity issues, we imposed a number of exclusion restrictions in our Heckman selection model. We estimate both types of model and let the t-test decide which should be preferred.

The two-part model simply consists in estimating the participation equation by Probit separately, namely estimating the probability that individuals remit positive amounts, and the amount of remittances by OLS on the subsample of observations for which the remittances are positive. In other words, the model is modified as follows: 


$$
\begin{aligned}
& d_{i}^{*}=z_{i}^{\prime} \beta_{1}+\varepsilon_{i} \text { with } d_{i}=\left\{\begin{array}{l}
1 \text { if } d_{1}^{*}>0 \\
0 \text { if } d_{1}^{*} \leq 0
\end{array}\right. \\
& \left(y_{i} \mid d_{i}^{*}>0\right)=x_{i}^{\prime} \beta_{2}+v_{i}
\end{aligned}
$$

Because of the way we constructed the participation variable, namely by attributing a zero whenever the level of remittance is zero and a 1 when it is greater than zero, double hurdle models would not improve our estimations in any way since one does not observe simultaneously participation and zero remittances. Double hurdle models will enable us to decompose the contribution to the likelihood of zero remittance observations between the behavioural zeros (non-participation) and the random zeros (participation but no remittances). To illustrate this, we can write the likelihood function for the double hurdle model with independence ${ }^{6}$ whose structure is given by:

$$
\begin{gathered}
d_{i}^{*}=z_{i}^{\prime} \beta_{1}+\varepsilon_{i} \text { with } d_{i}=\left\{\begin{array}{l}
1 \text { if } d_{1}^{*}>0 \\
0 \text { if } d_{1}^{*} \leq 0
\end{array}\right. \\
y_{i}^{*}=x_{i}^{\prime} \beta_{2}+v_{i} \text { with } y_{i}=\left\{\begin{array}{ll}
y_{i}^{*} & \text { if } d_{i}=1 \\
0 & \text { otherwise }
\end{array} \text { and } x_{i}^{\prime} \beta_{2}+v_{i}>0\right.
\end{gathered}
$$

And the likelihood to be maximized is:

$$
L=\prod_{i=1}^{n}\left[1-\Phi\left(z_{i}^{\prime} \beta_{1}\right) \Phi\left(\frac{x_{i}^{\prime} \beta_{2}}{\sigma}\right)\right]^{1-d_{i}}\left[\Phi\left(z_{i}^{\prime} \beta_{1}\right) \cdot \frac{1}{\sigma} \cdot \phi\left(\frac{y_{i}-x_{i}^{\prime} \beta_{2}}{\sigma}\right)\right]^{d_{i}} \text {, where } \Phi(.) \text { and } \phi(.) \text { are }
$$

respectively the normal cdf and pdf.

One can see that the only difference between this likelihood function and that given for the selection model is the inclusion of $\Phi\left(x_{i}^{\prime} \beta_{2} / \sigma\right)$ which takes care of cases where $\mathrm{d}=1$ but $y=0$. Since we don't have any observation corresponding to this situation, the double hurdle model would be equivalent to our selection model. Therefore it is not necessary to estimate double hurdle models for this analysis.

Altogether, we estimate four types of models: the basic Tobit, two-part model, model with selection estimated by Maximum likelihood and the Heckman two step model. It is to be noted that some of these models depend on the assumption of normality and homoskedasticity of the errors. If these assumptions fail, the estimated parameters are shown

\footnotetext{
${ }^{6}$ The same is true for the model with dependence. We choose the Cragg's specification for ease of presentation but the conclusion can be generalized to dependent hurdle models (Jones, 1992).
} 
to be inconsistent (Robinson, 1982). Therefore, we correct for multiplicative heteroskedasticity, specifying $\sigma_{i}=\exp \left(w_{i}^{\prime} \delta\right)$, with $w_{i}$ a set of variables assumed to cause heteroskedasticity. Moreover, because the migrants are interviewed several times in both cohorts (three times in cohort 1 and twice in the second cohort) we corrected the standard errors for clustering since the estimations didn't lend themselves to panel estimations due to limitations of the dataset and the instability they caused to the estimators. Correction for clustering enables us to take into account multiple observations for an individual but does not allow to model individual heterogeneity.

As regards the normality assumption, the literature proposes to transform the dependent variable whenever it is censored and over dispersed, which is the case for the observed remittances in our data. Indeed, remittances range from $\mathrm{A} \$ 10$ to $\mathrm{A} \$ 50,000$ in cohort 1 and from $\mathrm{A} \$ 11$ to $\mathrm{A} \$ 46,600$ in cohort 2, with a large mass point in 0 since it is censored. Given such over dispersion, the transformation is necessary in order to reduce the influence of extreme observations. Burbidge et al. (1988) show that the inverse hyperbolic sine transformation is superior to a Box-Cox transformation in handling extreme values. We therefore apply this transformation to the remittances. The inverse hyperbolic sine transformation is defined as: $y_{i}^{T}=\ln \left(y+\sqrt{\gamma^{2} y^{2}+1}\right) / \gamma$, with $\gamma$ as an extra parameter to be estimated. The likelihood functions are modified accordingly.

The comparison between remittance behaviour before and after the policy change is captured in the estimations through the incorporation of a dichotomic variable taking value 1 if the migrant arrived after the policy change. In addition, we interact this dummy with a number of variables assumed to determine the level of remittances. This enables us to obtain difference in difference estimators for these variables. The estimated parameter indicates to what extent the influence of these variables has changed, if at all, after the new policy. More specifically, we wonder whether the policy change affected the remittance behaviour differently depending on the region of birth, the labour force status or the visa type ${ }^{7}$. With respect to the visa type, we know that migrants arriving under humanitarian visas (refugees) do not have to wait the 2 years period to be eligible for welfare payments, contrary to most other visa categories under the new policy. By interacting cohort and refugee visa we can determine the difference in terms of occurrence and level of remittances between two refugees, one arriving with the first cohort, the second after the policy change. It is also

\footnotetext{
${ }^{7}$ Identification and convergence issues prevent us from interacting cohort with all the regressors of each equation.
} 
interesting to look at the effect of the migrant's region of origin on both decisions (probability and level of remittances) since the policy change may have a bigger impact on migrants coming from developing regions (e.g. South Asia etc) than those from the developed one (e.g., USA, Western Europe etc).. If significant differences are observed for various regions, it implies that the policy change in Australia also has repercussions for the sending regions. The descriptive statistics seemed to indicate discrepancies among regions of origin. The estimations will enable us to conclude whether these discrepancies remain after controlling for a range of individual characteristics.

In the estimations, we also control for individuals' labour force status and family arrangements in order to make individuals comparable between cohorts since each cohort faced slightly different labour market conditions upon arrival. Tougher selection criteria can also imply potentially higher levels of labour force participation. We interact the labour force status variables with the cohort dummy to see if two migrants with the same labour force status and comparable in terms of individual characteristics, but arriving under different policy regime, exhibit different remittance behaviours.

\section{Estimation Results}

Tables 9 and 10 report the estimation results. Table 9 includes the results from a basic Tobit and a model with selection estimated by maximum likelihood. Table 10 reports the results of the two-part model and two-step selection. Based on Information criteria, Vuong and Distribution Free test, it appears that the two-part model and two-step selection give better estimates than the other two used in Table 9. Among those used in Table 10, the twostep selection gives slightly better estimates than the two-part model, though overall the results are rather similar. Therefore, in the following, we exploit the results from the former model (Table 10), including the discussion on the probability to remit.

It is interesting to notice the benefits from assuming that the decision to remit and the amounts of remittances are generated by different probability mechanisms. Indeed, the Tobit gives misleading results concerning the influence of the variables on the censored remittance levels since the better models not only show that the levels are determined by different variables but also that some variables affect participation and levels in opposite directions. Therefore, it makes sense to estimate a two equations model. In order to reduce the potential issue of collinearity between the Mills' ratio and the variables included in the second 
equation, we imposed some exclusion restrictions in the estimations of the probability to remit.

\subsection{The Decision to Remit}

It appears that the residual effect of cohort is negative. Migrants arriving after the policy change have a lower probability to remit (about 8.6\%) than those who entered before the change (cohort 1). Given that we control for a wide range of individual characteristics, including education levels, labour force status, region of origin , and other covariates, this result partly captures elements related to the selection of better migrants (aside from characteristics that are controlled for) and better macroeconomic environment experienced by second cohort migrants in Australia. Both elements meant that it was relatively easier to obtain gainful employment for those who entered after the policy change. Given our earlier discussion about immigrants remitting behaviour corresponding to a purchase of insurance in case of bad economic outcome, this result will then be consistent with a reduced need for buying that insurance and hence reducing the possibility of remittance flows in the initial stage of immigration episode. However, as argued by Stark (1991), contrary to some existing evidence, there is a potential for an increase in remittance flows as time spent in the host country increases. As remittances are part of migrant's implicit family insurance arrangement, in the case of successful migration experience, the migrant insures the family left behind against more risky investment activities. Our results are in line with this argument. Figure 3 illustrates the observation that first cohort migrants are systematically more likely to remit since arrival and throughout their stay in Australia. ${ }^{8}$

Individuals migrating under refugee protection visas have, on average, a higher probability (6.5\%) than non-refugees but this difference is halved in cohort 2. It is an interesting result since the policy change didn't have any discernable effect on those entering under refugee status as they are not subjected to the two years waiting period before eligibility to welfare payments. This result is not due to refugees being sourced from a different part of the world in cohort 2 compared to cohort 1 since we control for region of origin. It is unlikely that refugees remit because they feel the need to buy an insurance policy to hedge the risk associated with migrating. Rather, most refugees would send money back to help family members left behind in difficult situations. Therefore, if they do remit less after the policy change, it is likely caused by financial hardship in Australia despite their eligibility

\footnotetext{
${ }^{8}$ Markova and Reilly (2007) get the same result for Bulgarian immigrants who legally entered Spain prior to Bulgaria's accession to the EU.
} 
to welfare payments. Since the selection criteria for migration have changed and have led to the arrival of more skilled and employable migrants, refugees arriving with the second cohort may have faced fiercer competition in the labour market in Australia which may have reduced their ability to send remittances. They might also have chosen to live in different types of neighbourhood relative to those of the first cohort, though we do not have sufficient information to control for this possibility.

As regards the region of origin, there are noticeable differences in the probabilities to remit between migrants coming from Western (developed) regions and those coming from non-Western (less developed) regions. For instance, migrants from South Asia are 20\% more likely to remit than Westerners while people coming from North East Asia and Eastern Europe have $6.8 \%$ and $8 \%$ higher probabilities to remit respectively. The cohort effect significantly decreases the probabilities for some regions, i.e., Southern Europe, the Middle East and all of Asia, though non-Westerners still have a higher probability to remit. The biggest decrease in cohort 2 is observed for Southern Europe with a net positive effect of 2.5\% compared to Westerners in cohort 2, falling from 10.5\% in cohort 1 (a decrease of 8 points between the two cohorts). We observe the same effect for Middle Eastern migrants. On the opposite, migrants coming from Eastern Europe do not have a significantly lower probability to remit after the policy change. It seems that the biggest drops are observed for migrants who come from countries associated to earlier waves of migration. Individuals coming from countries with a longer history of migration to Australia may benefit, to a larger extent, from social ethnic networks and may have more family members and friends already present in Australia which reduces their need to send money abroad. Figures 4 and 5 illustrate with more details the differences between countries for the two cohorts regarding probabilities to remit. The profiles of the probabilities per country according to the time spent in Australia are distinctly different between the two cohorts. After the policy change the profiles of the probabilities are not only flatter but they also illustrate some significant changes in the ordering of the countries.

Migrants' labour force status affects their probability to remit. Self-employed (or running a business employing others) and wage earners are more likely to remit than individuals who are not in the labour force (including students). On the contrary, unemployed individuals are less likely to remit. Interestingly, cohort 2 migrants are not different from the first cohort as regards the influence of the labour force status on the probabilities to remit; wage earners remain about $8.7 \%$ more likely to remit as well as business owners who have a 3.3\% higher probability. 
As regards the highest level of education attained, it is interesting to notice that most coefficients are not significant except for individuals who only completed primary or secondary school. These are more likely to remit than someone with a university degree. Adding interaction terms between cohort and education levels lead to the same results ${ }^{9}$, indicating that no significant change occurs as regards the effect of education on the probability to remit after the policy change. This result shows that education by itself does not have an impact on the remittance behaviour but rather on the labour market performance. Language ability also affects the probabilities. Migrants reporting that they speak English very well (or well) are more likely to remit.

Individuals who visited Australia before deciding to migrate and who have been shown to experience better labour market outcomes (Mahuteau and Junankar, 2008) are 5\% less likely to remit. These are probably individuals with greater financial means who could afford spending some time in Australia before migrating. Along the same lines, the more funds individuals brought with them to Australia, the less likely they are to remit.

The household size negatively affects the probability to remit. This is commonly observed in the literature for other countries (Sinning, 2007). Married individuals are more likely to remit. This is consistent with results obtained in the literature on remittance behaviour.

Overall the main difference between the two cohorts as regards the probability to remit is a negative residual cohort effect of $-8.65 \%$. The labour force status does not affect the probability to remit.

\subsection{The value of remittances}

It is clear from Table 10 that some determinants affect the probability to remit in one way but the level of remittances in the opposite direction, especially in the case of cohort 2 The migrants in the second cohort are less likely to remit but, when they do, they remit higher amount than those in the first cohort.

The results show that the variables assumed to affect individuals' remittance behaviour influence the probabilities to remit to a larger extent than the actual level of remittances. Although the regional effect was important in determining the probabilities, it hardly plays any role on the expected level of remittances. The results of a nested test

\footnotetext{
${ }^{9}$ Results not reported in this paper but available on request
} 
between the displayed model and the one model restricting the regions of origin parameters to be zero leads to reject the latter model.

The ability to pay is expected to affect the remittance levels to a larger extent than the probabilities to remit. Looking at the results obtained for the income categories, perhaps not surprisingly, individuals with higher average income remit more than people with intermediate income, while individuals belonging in the lower income bracket (A \$155 to A \$385 a week) remit significantly less. As migrants are interviewed fairly early after arrival, it is possible that they are still in the early process of settlement and face a greater uncertainty about their future income. The omitted category of income corresponds for both cohort 1 and 2 migrants to the median weekly income in Australia (sourced from the Australian Bureau of Statistics (ABS). The result shows that so long as migrants are below this threshold, their remittances are significantly lower.

Business owners and self employed individuals are not only more likely to remit but also remit more than wage earners. Using German Socio-economic Panel data, Dustmann (1999) showed that business owners in the host country are more likely to return to their home country before retirement and run a business upon return. This may explain why they remit more to their home country, contrasting with those who plan to stay permanently in the host country or move back after retirement. Wage earners are more likely to invest in human capital in the host country and therefore stay longer in order to make their investment more profitable. Those returning as retirees tend to accumulate their savings in the country that offers higher returns (or security), hence a smaller part of their savings is sent back abroad. Yet, it appears that second cohort migrants who run a business remit less than those in the first cohort. Given that second cohort migrants faced better macroeconomic conditions in Australia, it is less likely that they didn't have the ability to remit a higher amount. Thus the alternative reason on why remittances should have dropped for these individuals is possibly more to do with them facing less uncertainty about the economic survival of their business venture, compared to the business owners in the first cohort. This then corresponds to the often discussed argument in the literature of migrants' remittance decision as part of the insurance motive to hedge against a possible failure of the migration experience. In other words, the insurance motive for the second cohort was considerably lower than for the first cohort.

Household size has a negative impact on the probability and the level of remittances, which is consistent with the existing literature (see Sinning, 2007). The effect of being married on remittances is not as straightforward since it has a positive effect on the 
probability but a negative influence on the level. Since we control for household size in the estimations, the lower level of remittances observed for married couples is not immediately due to having dependents to take care of in Australia. This effect can be due to having larger expenses like dwellings and food, among others. As for the larger probability, it can be that as a household, married migrants combine more relatives left in the origin country and consequently more individuals likely to be needing assistance via remittances.

Time spent in Australia positively affects both the level of remittances and the probability to remit. It is important to notice that this effect is controlled for the individuals' labour force status and income. This residual effect of time can be attributed, as the literature suggests to two associated factors. First, as time passes the fixed costs of settlement (e.g. furniture, car, etc.) decrease, improving migrants' ability to remit. Second, family and friends who stayed behind perhaps contributed a significant proportion of the migration costs. Therefore, as their ability to pay improves, this category of migrants remits more for the purpose of reimbursement of the financial contributions they benefited from. Unfortunately, the data does not allow us to check this as no useful information is available regarding how much financial help migrants received from family and friends. The interaction of time spent in Australia and cohort is positive but only significant with a p-value of $15 \%$. This effect is weak suggesting that there is not significantly different impact of time across cohorts.

Summarising the effect of being a cohort 2 migrant on the conditional expectation of remittances $\left(E\left(y_{i} \mid x_{i}, y_{i}^{*}>0\right)\right.$, after the policy change the probabilities to remit have been affected to a larger extent than the actual level of remittances for most individual characteristics. Table 11 shows the difference-in-difference estimators and cohort effects obtained for the conditional expectations. If a migrant remits, s/he tends to send more money after the policy change. The cohort effect influences the conditional expectation similarly across regions of origin and labour force status with a noticeable exception for the business owners who remit significantly less.

Tables 12, 13 and 14 give some estimates of the unconditional expectations of remittances across cohort for different visa categories, regions of origin and labour force status. They are given by:

$$
E\left(y_{i}\right)=\operatorname{Pr}\left(y_{i}^{*}>0\right) \cdot E\left(y_{i} \mid x_{i}, y_{i}^{*}>0\right)=\operatorname{Pr}\left(y_{i}^{*}>0\right) \cdot\left(x_{i}^{\prime} \beta_{2}+\rho \sigma \frac{\phi\left(z_{i}^{\prime} \beta_{1}\right)}{\Phi\left(z_{i}^{\prime} \beta_{1}\right)}\right) .
$$

Everything else held constant, upon arrival in cohort 1 a refugee is expected to remit an average of $A \$ 180$ and then increase the transfers to $A \$ 641$ in wave 2 and $A \$ 1305$ in the 
last wave. By comparison, a refugee from the second cohort remits A\$70 upon arrival and then moves on to $\mathrm{A} \$ 342$ in the last wave. The average unconditional expectations show some variability across countries, both in terms of level and variation across waves. Migrants from the UK, Western Europe and Oceania start in the first cohort with remittances below $\$ 100$ on average, against South Asians at A $\$ 337$. Even though the former group increases their remittances faster over time, by wave 3 migrants from South Asia still remain the highest remitters with A\$1851 on average. Migrants from the Middle East and Asia in general remit above A $\$ 1200$ by the third wave. Qualitatively, we find similar patterns in the second cohort except that the level of remittances is on average higher upon arrival compared to cohort 1 , except for people originating from South Europe, the Middle East, North America and South Asia but most differences are not significant. By the time of wave 2 of cohort 2, migrants from South Asia are again the largest remitters with $\mathrm{A} \$ 1118$, followed by Eastern Europe with A $\$ 840$. As regards the labour force status (Table 13), wage earners and business owners are remitting more in the first cohort with A $\$ 405$ and A $\$ 208$ respectively. By wave 3, that is beyond 24 months after arrival, business owners remit A \$1338 on average and wage earners A $\$ 1936$. As we have seen in the estimations above, business owner in cohort 2 remit significantly less. It is illustrated in Table 13 by average remittances of $A \$ 54$ in the first wave, increasing only up to A $\$ 242$.

\section{Conclusions}

Several aspects could influence the remittance flows from migrants to their families and friends in the sending countries. These range from repaying of loans to fund migration costs, altruism towards those who remain in the country of origin or indeed because of selfish reasons to curry favour with those remaining back home in case the migration experiment ends up in a failure (i.e., equivalent to taking insurance against bad economic outcome). These are also linked to migrants' skill level as relatively more educated are likely to secure stable employment and also more likely to move with their families compared to the low skilled. In this case there are potential benefits to the host country as skilled immigrants have a positive impact not only in terms of overcoming labour market shortages in high skill industries but also in terms of better economic assimilation resulting in higher investment and tax receipts in the host country. However, education can also have a positive effect on remittance flows as migration decision might be linked to obtain some target saving to start business in the home country, especially in the presence of credit constraints, which could indeed benefit the home country, possibly at the expense of the host country. 
We have analysed the impact of a change in immigration policy on the remittance behaviour of immigrants in Australia. The new policy, which was implemented after 1996, dramatically changed the conditions of entry making them more stringent both in terms of initial requirements (relatively higher skills and English language proficiency) and in terms of curbing the level of support offered upon entry. The analysis is done using two sets of the Longitudinal Survey of Immigrants in Australia. Our results point towards the direction of an overall negative relationship between stringent entry policy and the incidence of remittance flows. Those who entered in the second cohort, regardless of the origin region or type of job obtained, had a lower probability to remit compared to the first cohort. However, of those who did remit in the second cohort, the average level was higher than those who entered in the first cohort. In addition, not surprisingly both wage earners and self-employed are more likely to remit than unemployed. Finally, self-employed remit a higher amount than the wage earners. 


\section{References}

Amuedo-Dorantes, C. and S. Pozo (2006), "Remittances as Insurance: Evidence from Mexican Immigrants”, Journal of Population Economics, vol. 19, pp 227-254.

Blundell, R. and C. Meghir (1986) "Selection Criteria for a Microeconometric Model of Labor Supply”, Journal of Applied Econometrics, 1:1 (55-80)

Burbridge, J.B., L. Magee and A. Leslie Robb (1988). “Alternative Transformations to Handle Extreme Values of the Dependent Variable" Journal of the American Statistical Association 83(401): 123-127.

Chiswick, B.R. and P.W. Miller (2006), “Immigration to Australia during the 1990's: Institutional and labour market influences”, in D.A. Cobb-Clark and S. Khoo (eds.), Public Policy and Immigrant Settlement, Edward Elgar, Cheltenham, 2006, UK.

Clarke, K.A., (2007), “A Simple Distribution-Free Test for Nonnested Model Selection”, Political Analysis (2007) 15:347-363

Cobb-Clark, (2000), Do Selection Criteria Make a Difference? Visa Category and the Labour Market Status of Immigrants to Australia, Economic Record, 76(232), pp 15-31

Cobb-Clark, D. (2003), "Public Policy and the Labor Market Adjustment of New Immigrants to Australia”, Journal of Population Economics, 16, pp. 655-681.

Cobb-Clark, D. (2004), "Selection Policy and the Labour Market Outcomes of New Immigrants”, IZA Discussion Paper No. 1380.

Cragg, J. (1971) "Some Statistical Models for Limited Dependent Variables with Application to the Demand for Durable Goods,” Econometrica, 39:5 (829-844).

Dustmann, C., (1999). "Temporary Migration, Human Capital and Language Fluency of Migrants”, Scandinavian Journal of Economics, 101, 297-314, 1999

Dustmann, C., \& Kirchkamp, O. (2002). The optimal migration duration and activity choice after re-migration. Journal of Development Economics, 67 (2), 351-372.

Duleep, H. O. and Regets, M.C. (1996), “Admission Criteria and Immigrant Earnings Profiles.” International Migration Review 30(2): 571 - 590.

Greene, W.H. (1996), Econometric Analysis, New York: Macmillan.

Hawthorne. L. (2005), “Picking winners: The Recent Transformation of Australia's Skill Migration Policy”, International Migration 39(3), 663-696. 
Hausman, J.A., (1978), “Specification tests in econometrics”, Econometrica 46, 1251-1272.

Hay, J., Leu, R. and Rohrer, P. (1987), Ordinary least squares and sample-selection models of health-care demand. Journal of Business and Economic Statistics 5, pp.499-506.

Heckman, J. (1979) “Sample Selection Bias as a Specification Error,” Econometrica, 47:1 (153-161).

Jasso, G. and Rosenzweig, M.R. (1995). "Do Immigrants Screened for Skills Do Better than Family Reunification Immigrants?” International Migration Review 29(1), pp. 85- 111.

Leung, S.F. and Yu, S. (2000), “Collinearity and Two-step Estimation of Sample Selection Models: Problems, Origins and Remedies”, Computational Economics 15, 173-199.

Mahuteau, S and Junankar, J.N. (2008), "Do Migrants Get Good Jobs in Australia? The Role of Ethnic Networks in Job Search”, IZA DP No. 3489

Manning, W., N. Duan, W. Rogers. (1987), "Monte Carlo evidence on the choice between sample selection and two-part models”, Journal of Econometrics 35, 59 82.

Moffatt, P. (2005) “Hurdle Models of Loan Default,” Journal of the Operational Research Society, 56 (1063-1071).

Piracha, M and Vadean, F. (2010), "Return Migration and Occupational Choice: Evidence from Albania”, World Development, Article in Press.

Piracha, M and Zhu, Y. (2007), "Precautionary Savings by Natives and Immigrants in Germany”, IZA Discussion Paper No. 2942

Markova, E. and B. Reilly (2007), "Bulgarian migrant remittances and legal status: some micro-level evidence from Madrid”, South-Eastern Europe Journal of Economics, Vol. 5, No.1 (Spring), pp.55-69

Shrestha, R., Alavalapati, J., Seidl, A., Weber, K. and Suselo, T. (2006), "Estimating the Local Cost of Protecting Koshi Tappu Wildlife Reserve, Nepal: A Contingent Valuation Approach,” Environment, Development and Sustainability, DOI 10.1007/s 10668-006-90294

Sinning M., (2007), Determinants of Savings and Remittances Empirical Evidence from Immigrants to Germany, IZA Discussion Paper no 2966.

Sorensen, E., Bean, F.D., Leighton, K and Zimmermann, W. (1992), Immigrant Categories and The U.S. Job Market: Do They Make a Difference? Washington: The Urban Institute Press. 
Vuong, Q.H. (1989), “ Likelihood Ratio Tests for Model Selection and Non-Nested Hypotheses”, Econometrica, Vol. 57, No. 2, pp. 307-333

Watson, I. (1996), “Opening the glass door: overseas-born managers in Australia” AGPS, Canberra.

Wright, R. E. and Maxim, P. S. (1993), "Immigration Policy and Immigrant Quality: Empirical Evidence from Canada”, Journal of Population Economics, 6, pp. 337 - 352. 
Table 1: Migrants by visa categories

\begin{tabular}{lcc}
\hline Major Visa Category & LSIA 1 & LSIA2 \\
\hline Business (\%) & 3.44 & 5.79 \\
Family (\%) & 65.33 & 62.18 \\
Humanitarian (\%) & 14.12 & 7.44 \\
Independent (\%) & 17.12 & 24.59 \\
\hline
\end{tabular}

Table 2: Composition of immigrant population for cohort 1 (1993-1995) cohort 2 (1998-2000); by region of birth

\begin{tabular}{|c|c|c|c|c|}
\hline \multirow[b]{2}{*}{ Region of Birth } & \multicolumn{2}{|c|}{$\begin{array}{l}\text { Migrant population } \\
\text { arrived with cohort } 1\end{array}$} & \multicolumn{2}{|c|}{$\begin{array}{l}\text { Migrant population } \\
\text { arrived with cohort } 1\end{array}$} \\
\hline & Freq. & Percent & Freq. & Percent \\
\hline Oceania & 1,858 & 2.48 & 959 & 2.96 \\
\hline Great Britain & 11,454 & 15.27 & 4,752 & 14.66 \\
\hline South Europe & 6,530 & 8.71 & 2,293 & 7.07 \\
\hline Western Europe & 2,918 & 3.89 & 1,187 & 3.66 \\
\hline Eastern Europe & 3,505 & 4.67 & 993 & 3.06 \\
\hline Middle East & 7,383 & 9.84 & 3,356 & 10.35 \\
\hline South East Asia & 16,305 & 21.74 & 5,879 & 18.14 \\
\hline North East Asia & 10,245 & 13.66 & 5,259 & 16.23 \\
\hline South Asia & 7,208 & 9.61 & 3,437 & 10.6 \\
\hline North America & 2,685 & 3.58 & 1,112 & 3.43 \\
\hline Central, South America & 1,335 & 1.78 & 423 & 1.3 \\
\hline Africa & 3,563 & 4.75 & 2,764 & 8.53 \\
\hline Total & 74,990 & 100 & 32,415 & 100 \\
\hline
\end{tabular}

Table 3: Highest level of education completed by arrival cohort (percent of the immigrant population)

\begin{tabular}{lccccc}
\hline $\begin{array}{l}\text { Highest level of qualification } \\
\text { completed }\end{array}$ & $\begin{array}{c}\text { Cohort 1 } \\
\text { Wave 1 }\end{array}$ & $\begin{array}{c}\text { Cohort 1 } \\
\text { Wave2 }\end{array}$ & $\begin{array}{c}\text { Cohort 1 } \\
\text { Wave 3 }\end{array}$ & $\begin{array}{c}\text { Cohort 2 } \\
\text { Wave 1 }\end{array}$ & $\begin{array}{c}\text { Cohort2 } \\
\text { Wave 2 }\end{array}$ \\
\hline Primary school & 4.98 & 4.93 & 4.68 & 3.67 & 3.95 \\
Secondary school & 33.22 & 33.72 & 28.67 & 25.56 & 26.08 \\
Trade & 7.28 & 7.16 & 8.12 & 6.7 & 6.97 \\
technical/professional & 21.55 & 21.46 & 22.48 & 20.64 & 20.69 \\
Undergraduate Degree & 20.98 & 20.8 & 20.11 & 23.84 & 21.82 \\
Post graduate degree & 4.95 & 4.88 & 6.27 & 5.44 & 6.76 \\
Higher degree & 7.04 & 7.05 & 9.66 & 14.16 & 13.73 \\
\hline Total & $\mathbf{1 0 0}$ & $\mathbf{1 0 0}$ & $\mathbf{1 0 0}$ & $\mathbf{1 0 0}$ & $\mathbf{1 0 0}$ \\
\hline
\end{tabular}


Table 4: Labour Force Status in Australia by wave of interview and cohort (population)

\begin{tabular}{|c|c|c|c|c|c|}
\hline & \multicolumn{3}{|c|}{ Cohort1 } & \multicolumn{2}{|c|}{ Cohort2 } \\
\hline & wave 1 & wave 2 & wave 3 & wave 1 & wave 2 \\
\hline $\begin{array}{l}\text { Business Owner (employing } \\
\text { others, self employed) }\end{array}$ & $2.97 \%$ & $4.93 \%$ & $6.40 \%$ & $5.05 \%$ & $8.42 \%$ \\
\hline $\begin{array}{l}\text { Business owner, self } \\
\text { employed }\end{array}$ & $2.28 \%$ & $3.54 \%$ & $4.55 \%$ & $3.69 \%$ & $6.41 \%$ \\
\hline $\begin{array}{l}\text { Business owner employing } \\
\text { others }\end{array}$ & $0.68 \%$ & $1.38 \%$ & $1.86 \%$ & $1.36 \%$ & $2.02 \%$ \\
\hline Wage earner & $31.83 \%$ & $42.84 \%$ & $48.44 \%$ & $45.80 \%$ & $53.55 \%$ \\
\hline Other employed & $0.48 \%$ & $0.84 \%$ & $0.13 \%$ & $0.29 \%$ & $0.26 \%$ \\
\hline $\begin{array}{l}\text { Unemployed looking for full time } \\
\text { or part time job }\end{array}$ & $22.63 \%$ & $13.94 \%$ & $10.33 \%$ & $11.18 \%$ & $7.20 \%$ \\
\hline $\begin{array}{l}\text { Unemployed looking for } \\
\text { full time job }\end{array}$ & $20.43 \%$ & $12.22 \%$ & $8.39 \%$ & $9.28 \%$ & $5.53 \%$ \\
\hline $\begin{array}{l}\text { Unemployed looking for } \\
\text { part time job }\end{array}$ & $2.20 \%$ & $1.72 \%$ & $1.94 \%$ & $1.89 \%$ & $1.66 \%$ \\
\hline Student & $16.21 \%$ & $13.57 \%$ & $6.74 \%$ & $15.15 \%$ & $8.09 \%$ \\
\hline Not in the labour force & $25.87 \%$ & $23.88 \%$ & $27.95 \%$ & $22.53 \%$ & $22.48 \%$ \\
\hline
\end{tabular}

Table 5: Percent of migrant population remitting by interview wave (population)

\begin{tabular}{ccc}
\hline & $\begin{array}{c}\text { Percent remitting } \\
\text { (population) }\end{array}$ & $\begin{array}{c}\text { Average value of } \\
\text { remittances in AUD } \\
\text { (population) }\end{array}$ \\
\hline cohort 1 wave 1 & $7.76 \%$ & 93.11 \\
cohort 1 wave 2 & $22.00 \%$ & 348.28 \\
cohort 1 wave 3 & $31.05 \%$ & 770.71 \\
cohort 2 wave 1 & $4.20 \%$ & 76.08 \\
cohort 2 wave 2 & $13.40 \%$ & 355.26 \\
\hline
\end{tabular}

Table 6: Amount of remittances sent abroad by time since arrival, AUD 2000 (population)

\begin{tabular}{lccc}
\hline Remittances (\$) & Observations & Mean & Std. Dev. \\
\hline Cohort 1 & & & \\
6 mths or less & 4379 & 85.88 & 566.86 \\
6 to 12 mths & 794 & 146.89 & 755.74 \\
12 to 18 mths & 3491 & 350.12 & 1727.31 \\
18 to 24 mths & 980 & 337.45 & 1154.01 \\
24 mths or more & 3757 & 766.81 & 2583.35 \\
Cohort 2 & & & \\
6 mths or less & 2329 & 69.62 & 472.09 \\
6 to 12 mths & 794 & 93.76 & 497.28 \\
12 to 18 mths & 1713 & 367.88 & 1612.56 \\
18 to 24 mths & 917 & 336.09 & 1145.83 \\
24 mths or more & 17 & 30.86 & 167.24 \\
\hline
\end{tabular}


Table 7: Percent of migrants remitting by country of origin (population)

\begin{tabular}{lccccccc}
\hline & \multicolumn{3}{c}{ Cohort 1 } & \multicolumn{3}{c}{ Cohort 2 } \\
& all waves & wave1 & wave2 & wave3 & all waves & wave1 & wave2 \\
\hline Western Industrialized & $\mathbf{7 . 9 2 \%}$ & $6.79 \%$ & $8.43 \%$ & $8.55 \%$ & $\mathbf{3 . 5 2 \%}$ & $2.23 \%$ & $4.80 \%$ \\
Country & $\mathbf{1 5 . 7 2 \%}$ & $8.93 \%$ & $17.11 \%$ & $21.13 \%$ & $\mathbf{9 . 5 8 \%}$ & $3.59 \%$ & $15.57 \%$ \\
South America, Africa & $\mathbf{1 7 . 0 4 \%}$ & $6.50 \%$ & $19.73 \%$ & $24.89 \%$ & $\mathbf{4 . 5 6 \%}$ & $2.16 \%$ & $6.95 \%$ \\
South Europe & $\mathbf{1 3 . 9 4 \%}$ & $3.92 \%$ & $15.25 \%$ & $22.66 \%$ & $\mathbf{9 . 1 8 \%}$ & $5.61 \%$ & $12.76 \%$ \\
Eastern Europe & $\mathbf{1 6 . 5 4 \%}$ & $6.98 \%$ & $18.76 \%$ & $23.88 \%$ & $\mathbf{5 . 2 3 \%}$ & $1.31 \%$ & $9.15 \%$ \\
Middle East & $\mathbf{2 1 . 8 4 \%}$ & $10.75 \%$ & $23.61 \%$ & $31.15 \%$ & $\mathbf{1 0 . 6 5 \%}$ & $5.48 \%$ & $15.82 \%$ \\
South East Asia & $\mathbf{1 0 . 8 3 \%}$ & $4.98 \%$ & $12.24 \%$ & $15.26 \%$ & $\mathbf{3 . 9 0 \%}$ & $2.46 \%$ & $5.34 \%$ \\
North East Asia & $\mathbf{2 5 . 5 1 \%}$ & $10.25 \%$ & $28.93 \%$ & $37.36 \%$ & $\mathbf{1 0 . 3 1 \%}$ & $5.67 \%$ & $14.95 \%$ \\
\hline South Asia & & & & & & &
\end{tabular}

Table 8: Amount of remittances sent abroad by country of origin, AUD 2000 (population)

\begin{tabular}{lccccccc}
\hline & \multicolumn{4}{c}{ Cohort 1 } & \multicolumn{4}{c}{ Cohort 2 } \\
& all waves & wave1 & wave2 & wave3 & all waves & wave1 & wave2 \\
\hline Western Industrialized & $\mathbf{2 7 4 . 9 7}$ & 133.29 & 294.29 & 454.71 & $\mathbf{1 3 8 . 4 5}$ & 44.33 & 252.57 \\
Country & $\mathbf{3 1 9 . 3 1}$ & 81.47 & 278.79 & 700.00 & $\mathbf{2 5 9 . 9 8}$ & 80.87 & 466.97 \\
South America, Africa & $\mathbf{2 9 0 . 8 6}$ & 51.37 & 230.56 & 693.24 & $\mathbf{1 0 0 . 5 2}$ & 36.13 & 174.09 \\
South Europe & $\mathbf{2 5 9 . 0 0}$ & 26.78 & 169.08 & 660.72 & $\mathbf{1 8 3 . 8 6}$ & 80.55 & 305.11 \\
Eastern Europe & $\mathbf{3 5 4 . 4 9}$ & 55.97 & 284.56 & 852.03 & $\mathbf{7 9 . 1 6}$ & 13.18 & 156.51 \\
Middle East & $\mathbf{4 4 2 . 8 4}$ & 112.41 & 408.00 & 932.92 & $\mathbf{2 6 0 . 6 8}$ & 92.29 & 459.29 \\
South East Asia & $\mathbf{5 0 0 . 9 1}$ & 107.27 & 433.60 & 1205.04 & $\mathbf{1 3 3 . 0 4}$ & 51.11 & 233.78 \\
North East Asia & $\mathbf{5 9 1 . 8 2}$ & 118.01 & 567.56 & 1221.92 & $\mathbf{3 0 3 . 2 5}$ & 109.41 & 523.17 \\
\hline South Asia & & & & & &
\end{tabular}


Table 9: Estimation results, Tobit and Selection model (MLE)

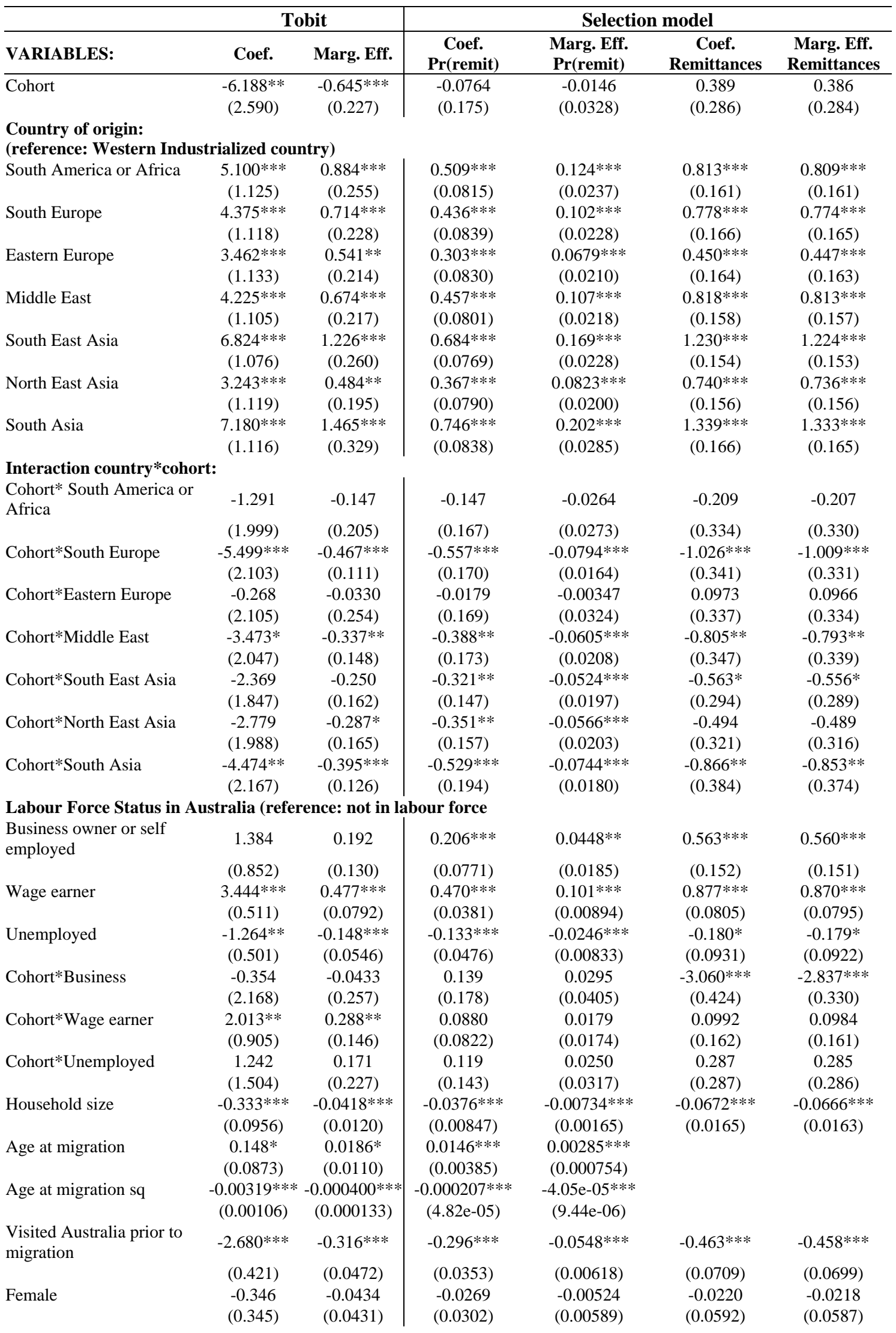


English language ability: (reference: Does not speak well)

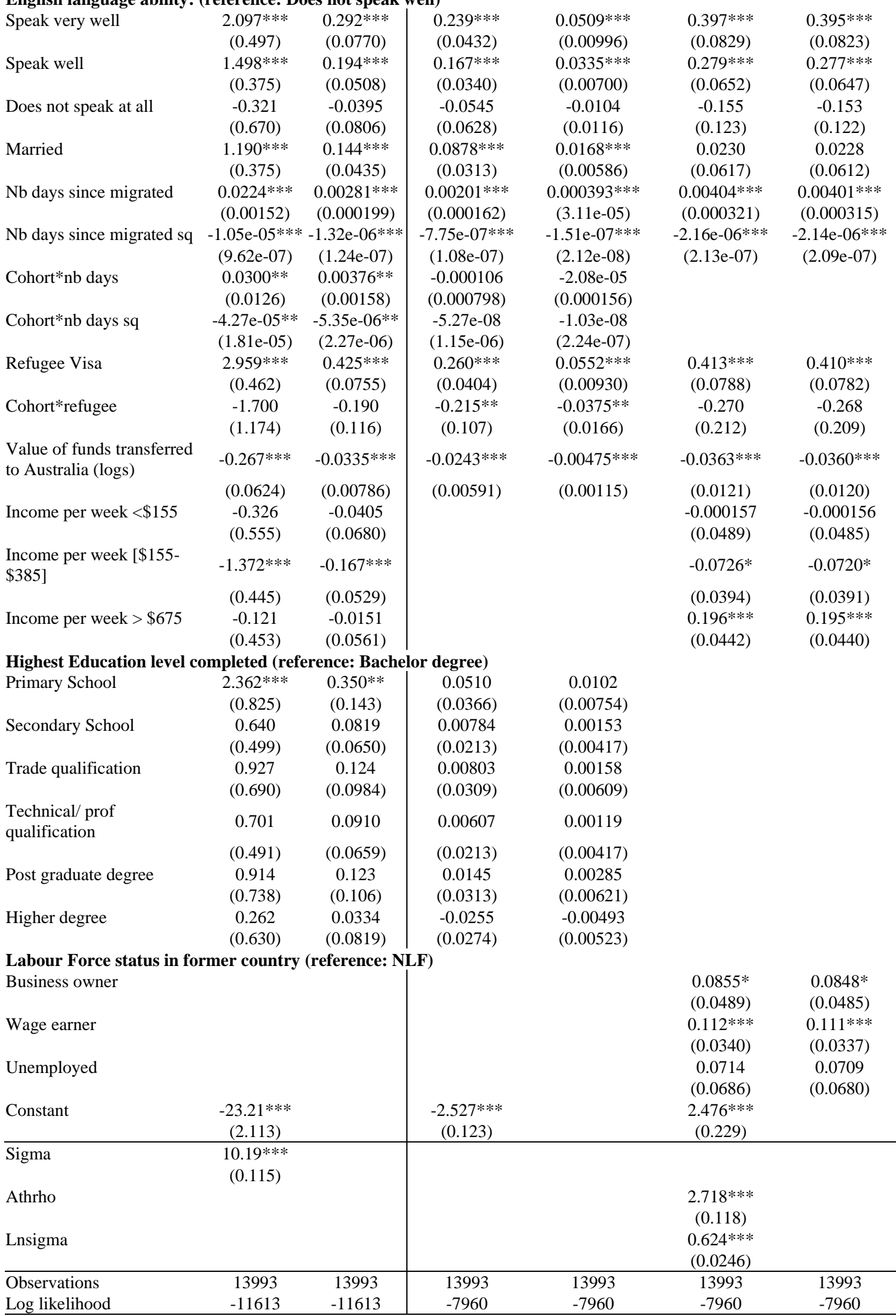

Note: Robust standard errors in parentheses $* * * \mathrm{p}<0.01$, ** $\mathrm{p}<0.05$, ${ }^{*} \mathrm{p}<0.1$ 
Table 10: Estimation result, Two-part model and Two-step selection model

\begin{tabular}{|c|c|c|c|c|c|c|}
\hline \multirow[b]{2}{*}{ VARIABLES } & \multicolumn{3}{|c|}{ Two part model } & \multicolumn{3}{|c|}{ Heckman two-step } \\
\hline & $\begin{array}{c}\text { Coef. } \\
\text { Pr(remit) }\end{array}$ & $\begin{array}{l}\text { Marg Eff. } \\
\text { Pr(remit) }\end{array}$ & $\begin{array}{c}\text { Coef. } \\
\text { Remittances }\end{array}$ & $\begin{array}{c}\text { Coef. } \\
\text { Pr(remit) }\end{array}$ & $\begin{array}{l}\text { Marg Eff. } \\
\text { Pr(remit) }\end{array}$ & $\begin{array}{c}\text { Coef. } \\
\text { Remittances }\end{array}$ \\
\hline Cohort & $\begin{array}{c}-0.514^{* *} \\
(0.255)\end{array}$ & $\begin{array}{c}-0.0870 * * \\
(0.0376)\end{array}$ & $\begin{array}{c}0.526^{* * *} \\
(0.195)\end{array}$ & $\begin{array}{c}-0.512 * * \\
(0.247)\end{array}$ & $\begin{array}{c}-0.0865 * * \\
(0.0362)\end{array}$ & $\begin{array}{c}0.509 * * \\
(0.257)\end{array}$ \\
\hline \multicolumn{7}{|c|}{ Country of origin: (reference: Western Industrialized country) } \\
\hline South America or Africa & $\begin{array}{c}0.530 * * * \\
(0.115)\end{array}$ & $\begin{array}{l}0.129 * * * \\
(0.0332)\end{array}$ & $\begin{array}{l}-0.0640 \\
(0.152)\end{array}$ & $\begin{array}{l}0.525^{* * *} \\
(0.0843)\end{array}$ & $\begin{array}{l}0.127 * * * \\
(0.0245)\end{array}$ & $\begin{array}{l}0.0266 \\
(0.164)\end{array}$ \\
\hline South Europe & $\begin{array}{c}0.453^{* * * *} \\
(0.114)\end{array}$ & $\begin{array}{l}0.106 * * * \\
(0.0308)\end{array}$ & $\begin{array}{l}0.0702 \\
(0.155)\end{array}$ & $\begin{array}{l}0.451 * * * \\
(0.0867)\end{array}$ & $\begin{array}{l}0.105^{* * *} \\
(0.0236)\end{array}$ & $\begin{array}{c}0.151 \\
(0.160)\end{array}$ \\
\hline Eastern Europe & $\begin{array}{c}0.363^{* * *} \\
(0.115)\end{array}$ & $\begin{array}{c}0.0822 * * * \\
(0.0298)\end{array}$ & $\begin{array}{l}-0.152 \\
(0.154)\end{array}$ & $\begin{array}{l}0.358 * * * \\
(0.0863)\end{array}$ & $\begin{array}{c}0.0807 * * * \\
(0.0224)\end{array}$ & $\begin{array}{l}-0.0883 \\
(0.147)\end{array}$ \\
\hline Middle East & $\begin{array}{c}0.427 * * * \\
(0.112)\end{array}$ & $\begin{array}{c}0.0976 * * * \\
(0.0295)\end{array}$ & $\begin{array}{c}0.110 \\
(0.150)\end{array}$ & $\begin{array}{c}0.427 * * * \\
(0.0833)\end{array}$ & $\begin{array}{c}0.0973 * * * \\
(0.0220)\end{array}$ & $\begin{array}{c}0.192 \\
(0.155)\end{array}$ \\
\hline South East Asia & $\begin{array}{c}0.717^{* * *} \\
(0.110)\end{array}$ & $\begin{array}{l}0.177 * * * \\
(0.0326)\end{array}$ & $\begin{array}{l}0.0339 \\
(0.145)\end{array}$ & $\begin{array}{l}0.715^{* * *} \\
(0.0800)\end{array}$ & $\begin{array}{l}0.176^{* * *} \\
(0.0239)\end{array}$ & $\begin{array}{c}0.149 \\
(0.184)\end{array}$ \\
\hline North East Asia & $\begin{array}{c}0.325^{* * *} \\
(0.112)\end{array}$ & $\begin{array}{c}0.0709 * * * \\
(0.0271)\end{array}$ & $\begin{array}{c}0.460 * * * \\
(0.164)\end{array}$ & $\begin{array}{l}0.316 * * * \\
(0.0826)\end{array}$ & $\begin{array}{c}0.0685^{* * * *} \\
(0.0200)\end{array}$ & $\begin{array}{c}0.521^{* * *} \\
(0.142)\end{array}$ \\
\hline South Asia & $\begin{array}{c}0.766 * * * \\
(0.116)\end{array}$ & $\begin{array}{l}0.207 * * * \\
(0.0391)\end{array}$ & $\begin{array}{c}0.140 \\
(0.154)\end{array}$ & $\begin{array}{l}0.765^{* * *} \\
(0.0873)\end{array}$ & $\begin{array}{l}0.206 * * * \\
(0.0297)\end{array}$ & $\begin{array}{c}0.258 \\
(0.194)\end{array}$ \\
\hline \multicolumn{7}{|l|}{ Interaction country*cohort: } \\
\hline Cohort* South America or Africa & $\begin{array}{l}-0.157 \\
(0.197)\end{array}$ & $\begin{array}{l}-0.0275 \\
(0.0314)\end{array}$ & $\begin{array}{c}0.289 \\
(0.225)\end{array}$ & $\begin{array}{c}-0.166 \\
(0.171)\end{array}$ & $\begin{array}{l}-0.0290 \\
(0.0268)\end{array}$ & $\begin{array}{c}0.262 \\
(0.288)\end{array}$ \\
\hline Cohort*South Europe & $\begin{array}{c}-0.576^{* * * *} \\
(0.206)\end{array}$ & $\begin{array}{c}-0.0799 * * * \\
(0.0189)\end{array}$ & $\begin{array}{l}0.0718 \\
(0.247)\end{array}$ & $\begin{array}{c}-0.579 * * * \\
(0.174)\end{array}$ & $\begin{array}{c}-0.0799 * * * * \\
(0.0159)\end{array}$ & $\begin{array}{l}-0.0160 \\
(0.325)\end{array}$ \\
\hline Cohort*Eastern Europe & $\begin{array}{l}-0.0521 \\
(0.208)\end{array}$ & $\begin{array}{l}-0.00975 \\
(0.0377)\end{array}$ & $\begin{array}{l}0.396^{*} \\
(0.226)\end{array}$ & $\begin{array}{l}-0.0492 \\
(0.173)\end{array}$ & $\begin{array}{l}-0.00919 \\
(0.0315)\end{array}$ & $\begin{array}{c}0.382 \\
(0.293)\end{array}$ \\
\hline Cohort*Middle East & $\begin{array}{l}-0.356^{*} \\
(0.201)\end{array}$ & $\begin{array}{c}-0.0557 * * \\
(0.0248)\end{array}$ & $\begin{array}{l}-0.0702 \\
(0.216)\end{array}$ & $\begin{array}{c}-0.374 * * \\
(0.177)\end{array}$ & $\begin{array}{c}-0.0578 * * * \\
(0.0212)\end{array}$ & $\begin{array}{l}-0.141 \\
(0.319)\end{array}$ \\
\hline Cohort*South East Asia & $\begin{array}{l}-0.282 \\
(0.183)\end{array}$ & $\begin{array}{c}-0.0465^{*} \\
(0.0252)\end{array}$ & $\begin{array}{l}0.0855 \\
(0.203)\end{array}$ & $\begin{array}{c}-0.281 * \\
(0.151)\end{array}$ & $\begin{array}{c}-0.0461^{* *} \\
(0.0208)\end{array}$ & $\begin{array}{l}0.0246 \\
(0.265)\end{array}$ \\
\hline Cohort*North East Asia & $\begin{array}{l}-0.287 \\
(0.194)\end{array}$ & $\begin{array}{c}-0.0473^{*} \\
(0.0267)\end{array}$ & $\begin{array}{l}-0.0696 \\
(0.264)\end{array}$ & $\begin{array}{c}-0.277^{*} \\
(0.162)\end{array}$ & $\begin{array}{c}-0.0458^{* *} \\
(0.0226)\end{array}$ & $\begin{array}{l}-0.0980 \\
(0.295)\end{array}$ \\
\hline Cohort*South Asia & $\begin{array}{c}-0.518 * * \\
(0.215)\end{array}$ & $\begin{array}{c}-0.0722 * * * \\
(0.0200)\end{array}$ & $\begin{array}{c}0.164 \\
(0.246)\end{array}$ & $\begin{array}{c}-0.517 * * * \\
(0.200)\end{array}$ & $\begin{array}{c}-0.0719 * * * \\
(0.0185)\end{array}$ & $\begin{array}{l}0.0742 \\
(0.342)\end{array}$ \\
\hline \multicolumn{7}{|c|}{ Labour Force Status in Australia (reference: not in labour force } \\
\hline Business owner or self employed & $\begin{array}{l}0.177^{* *} \\
(0.0852)\end{array}$ & $\begin{array}{l}0.0375^{*} \\
(0.0196)\end{array}$ & $\begin{array}{c}0.362 * * \\
(0.148)\end{array}$ & $\begin{array}{c}0.158^{*} \\
(0.0812)\end{array}$ & $\begin{array}{l}0.0329 * \\
(0.0183)\end{array}$ & $\begin{array}{c}0.387 * * * \\
(0.124)\end{array}$ \\
\hline Wage earner & $\begin{array}{l}0.421^{* * *} \\
(0.0435)\end{array}$ & $\begin{array}{c}0.0881 * * * \\
(0.00995)\end{array}$ & $\begin{array}{c}0.194 * * * \\
(0.0749)\end{array}$ & $\begin{array}{c}0.419 * * * \\
(0.0403)\end{array}$ & $\begin{array}{l}0.0875 * * * \\
(0.00917)\end{array}$ & $\begin{array}{c}0.246 * * \\
(0.105)\end{array}$ \\
\hline Unemployed & $\begin{array}{c}-0.145^{* * *} \\
(0.0510)\end{array}$ & $\begin{array}{c}-0.0262 * * * \\
(0.00869)\end{array}$ & $\begin{array}{l}-0.00138 \\
(0.0679)\end{array}$ & $\begin{array}{c}-0.147 * * * \\
(0.0489)\end{array}$ & $\begin{array}{c}-0.0265 * * * \\
(0.00830)\end{array}$ & $\begin{array}{l}-0.0134 \\
(0.0755)\end{array}$ \\
\hline Cohort*Business & $\begin{array}{l}-0.0476 \\
(0.210)\end{array}$ & $\begin{array}{l}-0.00892 \\
(0.0383)\end{array}$ & $\begin{array}{l}-0.664 \\
(0.706)\end{array}$ & $\begin{array}{l}-0.0322 \\
(0.199)\end{array}$ & $\begin{array}{l}-0.00608 \\
(0.0369)\end{array}$ & $\begin{array}{l}-0.692 * \\
(0.390)\end{array}$ \\
\hline Cohort*Wage earner & $\begin{array}{c}0.138 \\
(0.0900)\end{array}$ & $\begin{array}{c}0.0284 \\
(0.0196)\end{array}$ & $\begin{array}{l}-0.193 * * \\
(0.0862)\end{array}$ & $\begin{array}{c}0.133 \\
(0.0842)\end{array}$ & $\begin{array}{c}0.0273 \\
(0.0183)\end{array}$ & $\begin{array}{l}-0.158 \\
(0.142)\end{array}$ \\
\hline Cohort*Unemployed & $\begin{array}{c}0.131 \\
(0.146)\end{array}$ & $\begin{array}{c}0.0272 \\
(0.0325)\end{array}$ & $\begin{array}{c}0.161 \\
(0.166)\end{array}$ & $\begin{array}{c}0.134 \\
(0.144)\end{array}$ & $\begin{array}{c}0.0278 \\
(0.0320)\end{array}$ & $\begin{array}{c}0.164 \\
(0.269)\end{array}$ \\
\hline Household size & $\begin{array}{c}-0.0351 * * * \\
(0.00998)\end{array}$ & $\begin{array}{c}-0.00677^{* * *} \\
(0.00192)\end{array}$ & $\begin{array}{l}-0.0191 \\
(0.0130)\end{array}$ & $\begin{array}{c}-0.0346 * * * \\
(0.00872)\end{array}$ & $\begin{array}{c}-0.00666 * * * \\
(0.00168)\end{array}$ & $\begin{array}{l}-0.0242 * \\
(0.0140)\end{array}$ \\
\hline Age at migration & $\begin{array}{c}0.0135 \\
(0.00900)\end{array}$ & $\begin{array}{c}0.00260 \\
(0.00173)\end{array}$ & & $\begin{array}{c}0.0142 * \\
(0.00802)\end{array}$ & $\begin{array}{l}0.00273^{*} \\
(0.00154)\end{array}$ & \\
\hline Age at migration sq & $\begin{array}{r}-0.000312^{* * *} \\
(0.000109)\end{array}$ & $\begin{array}{c}-6.02 \mathrm{e}-05^{* * *} \\
(2.10 \mathrm{e}-05)\end{array}$ & & $\begin{array}{c}-0.000318^{* * *} \\
(9.97 \mathrm{e}-05)\end{array}$ & $\begin{array}{c}-6.12 \mathrm{e}-05^{* * *} \\
(1.91 \mathrm{e}-05)\end{array}$ & \\
\hline Visited Australia prior to migration & $\begin{array}{c}-0.280^{* * *} \\
(0.0437)\end{array}$ & $\begin{array}{c}-0.0513 * * * \\
(0.00761)\end{array}$ & $\begin{array}{l}0.109 * * \\
(0.0549)\end{array}$ & $\begin{array}{c}-0.281^{* * *} \\
(0.0372)\end{array}$ & $\begin{array}{c}-0.0513 * * * \\
(0.00644)\end{array}$ & $\begin{array}{c}0.0639 \\
(0.0788)\end{array}$ \\
\hline Female & $\begin{array}{l}-0.0345 \\
(0.0356)\end{array}$ & $\begin{array}{l}-0.00664 \\
(0.00684)\end{array}$ & $\begin{array}{l}-0.0667 \\
(0.0508)\end{array}$ & $\begin{array}{l}-0.0341 \\
(0.0318)\end{array}$ & $\begin{array}{l}-0.00654 \\
(0.00609)\end{array}$ & $\begin{array}{l}-0.0628 \\
(0.0466)\end{array}$ \\
\hline \multicolumn{7}{|c|}{ English language ability: (reference: Does not speak well) } \\
\hline Speak very well & $\begin{array}{l}0.222^{* * *} \\
(0.0527)\end{array}$ & $\begin{array}{c}0.0464 * * * \\
(0.0119)\end{array}$ & $\begin{array}{c}0.0856 \\
(0.0622)\end{array}$ & $\begin{array}{l}0.224 * * * \\
(0.0478)\end{array}$ & $\begin{array}{c}0.0467 * * * \\
(0.0107)\end{array}$ & $\begin{array}{c}0.115 \\
(0.0725)\end{array}$ \\
\hline
\end{tabular}




\begin{tabular}{|c|c|c|c|c|c|c|}
\hline Speak well & $\begin{array}{l}0.158 * * * \\
(0.0395)\end{array}$ & $\begin{array}{l}0.0313 * * * \\
(0.00804)\end{array}$ & $\begin{array}{c}0.0646 \\
(0.0466)\end{array}$ & $\begin{array}{l}0.160 * * * \\
(0.0364)\end{array}$ & $\begin{array}{l}0.0315^{* * *} \\
(0.00737)\end{array}$ & $\begin{array}{c}0.0805 \\
(0.0558)\end{array}$ \\
\hline Does not speak at all & $\begin{array}{l}-0.0263 \\
(0.0680)\end{array}$ & $\begin{array}{l}-0.00500 \\
(0.0128)\end{array}$ & $\begin{array}{c}0.0433 \\
(0.0866)\end{array}$ & $\begin{array}{l}-0.0323 \\
(0.0671)\end{array}$ & $\begin{array}{l}-0.00611 \\
(0.0125)\end{array}$ & $\begin{array}{l}0.0276 \\
(0.102)\end{array}$ \\
\hline Married & $\begin{array}{l}0.134 * * * \\
(0.0395)\end{array}$ & $\begin{array}{c}0.0249 * * * \\
(0.00711)\end{array}$ & $\begin{array}{c}-0.238 * * * \\
(0.0489)\end{array}$ & $\begin{array}{l}0.132 * * * \\
(0.0332)\end{array}$ & $\begin{array}{l}0.0246^{* * *} \\
(0.00598)\end{array}$ & $\begin{array}{c}-0.223^{* * *} \\
(0.0509)\end{array}$ \\
\hline Nb days since migrated & $\begin{array}{c}0.00222 * * * \\
(0.000157)\end{array}$ & $\begin{array}{c}0.000428 * * * \\
(3.07 \mathrm{e}-05)\end{array}$ & $\begin{array}{c}0.000547^{* * *} \\
(0.000194)\end{array}$ & $\begin{array}{l}0.00223^{* * *} \\
(0.000179)\end{array}$ & $\begin{array}{c}0.000429 * * * \\
(3.43 \mathrm{e}-05)\end{array}$ & $\begin{array}{l}0.000858 * \\
(0.000499)\end{array}$ \\
\hline $\mathrm{Nb}$ days since migrated sq & $\begin{array}{c}-1.02 \mathrm{e}-06 * * * \\
(1.00 \mathrm{e}-07)\end{array}$ & $\begin{array}{c}-1.96 \mathrm{e}-07 * * * \\
(1.95 \mathrm{e}-08)\end{array}$ & $\begin{array}{l}-1.77 e-07 \\
(1.27 e-07)\end{array}$ & $\begin{array}{c}-1.03 \mathrm{e}-06^{* * * *} \\
(1.17 \mathrm{e}-07)\end{array}$ & $\begin{array}{c}-1.97 \mathrm{e}-07 * * * \\
(2.28 \mathrm{e}-08)\end{array}$ & $\begin{array}{l}-3.27 \mathrm{e}-07 \\
(2.61 \mathrm{e}-07)\end{array}$ \\
\hline Cohort*nb days & $\begin{array}{c}0.00276^{* *} \\
(0.00123)\end{array}$ & $\begin{array}{c}0.000532 * * \\
(0.000236)\end{array}$ & & $\begin{array}{l}0.00276^{*} \\
(0.00150)\end{array}$ & $\begin{array}{l}0.000530^{*} \\
(0.000288)\end{array}$ & $\begin{array}{c}0.0042 \\
(0.002923)\end{array}$ \\
\hline Cohort*nb days sq & $\begin{array}{c}-4.01 \mathrm{e}-06^{* *} \\
(1.76 \mathrm{e}-06)\end{array}$ & $\begin{array}{c}-7.73 \mathrm{e}-07^{* *} \\
(3.40 \mathrm{e}-07)\end{array}$ & & $\begin{array}{l}-4.03 e-06^{*} \\
(2.15 e-06)\end{array}$ & $\begin{array}{l}-7.75 \mathrm{e}-07^{*} \\
(4.12 \mathrm{e}-07)\end{array}$ & $\begin{array}{c}-5.52 \mathrm{e}-06 \\
4.15 \mathrm{e}-06\end{array}$ \\
\hline Refugee Visa & $\begin{array}{l}0.305^{* * *} \\
(0.0493)\end{array}$ & $\begin{array}{c}0.0650 * * * \\
(0.0115)\end{array}$ & $\begin{array}{l}0.00300 \\
(0.0630)\end{array}$ & $\begin{array}{c}0.303^{* * *} \\
(0.0429)\end{array}$ & $\begin{array}{c}0.0643^{* * *} \\
(0.00998)\end{array}$ & $\begin{array}{c}0.0356 \\
(0.0742)\end{array}$ \\
\hline Cohort*refugee & $\begin{array}{l}-0.207^{*} \\
(0.117)\end{array}$ & $\begin{array}{c}-0.0358^{* *} \\
(0.0180)\end{array}$ & $\begin{array}{l}-0.0674 \\
(0.117)\end{array}$ & $\begin{array}{l}-0.199 * \\
(0.109)\end{array}$ & $\begin{array}{c}-0.0345^{* *} \\
(0.0169)\end{array}$ & $\begin{array}{l}-0.0854 \\
(0.177)\end{array}$ \\
\hline $\begin{array}{l}\text { Value of funds transferred to Australia } \\
\text { (logs) }\end{array}$ & $\begin{array}{c}-0.0272^{* * *} \\
(0.00622)\end{array}$ & $\begin{array}{c}-0.00523 * * * \\
(0.00120)\end{array}$ & $\begin{array}{c}0.0331^{* * *} \\
(0.0127)\end{array}$ & $\begin{array}{c}-0.0268 * * * \\
(0.00623)\end{array}$ & $\begin{array}{c}-0.00516 * * * \\
(0.00120)\end{array}$ & $\begin{array}{l}0.0290 * * \\
(0.0117)\end{array}$ \\
\hline \multicolumn{7}{|l|}{$\begin{array}{l}\text { Highest Education level completed } \\
\text { (reference: Bachelor degree) }\end{array}$} \\
\hline Primary School & $\begin{array}{l}0.241 * * * \\
(0.0870)\end{array}$ & $\begin{array}{l}0.0525^{* *} \\
(0.0212)\end{array}$ & & $\begin{array}{l}0.244 * * * \\
(0.0740)\end{array}$ & $\begin{array}{c}0.0532 * * * \\
(0.0180)\end{array}$ & \\
\hline Secondary School & $\begin{array}{c}0.0740 \\
(0.0522)\end{array}$ & $\begin{array}{c}0.0145 \\
(0.0104)\end{array}$ & & $\begin{array}{l}0.0745^{*} \\
(0.0446)\end{array}$ & $\begin{array}{c}0.0145^{*} \\
(0.00884)\end{array}$ & \\
\hline Trade qualification & $\begin{array}{c}0.107 \\
(0.0732)\end{array}$ & $\begin{array}{c}0.0219 \\
(0.0157)\end{array}$ & & $\begin{array}{c}0.105 \\
(0.0656)\end{array}$ & $\begin{array}{c}0.0212 \\
(0.0140)\end{array}$ & \\
\hline Technical/ prof qualification & $\begin{array}{c}0.0797 \\
(0.0515)\end{array}$ & $\begin{array}{c}0.0158 \\
(0.0105)\end{array}$ & & $\begin{array}{l}0.0819^{*} \\
(0.0452)\end{array}$ & $\begin{array}{c}0.0162 * \\
(0.00922)\end{array}$ & \\
\hline Post graduate degree & $\begin{array}{c}0.0814 \\
(0.0778)\end{array}$ & $\begin{array}{c}0.0164 \\
(0.0163)\end{array}$ & & $\begin{array}{c}0.0840 \\
(0.0667)\end{array}$ & $\begin{array}{c}0.0169 \\
(0.0140)\end{array}$ & \\
\hline Higher degree & $\begin{array}{c}0.0260 \\
(0.0651)\end{array}$ & $\begin{array}{l}0.00507 \\
(0.0129)\end{array}$ & & $\begin{array}{c}0.0209 \\
(0.0571)\end{array}$ & $\begin{array}{l}0.00405 \\
(0.0112)\end{array}$ & \\
\hline Income per week $<\$ 155$ & & & $\begin{array}{l}-0.0267 \\
(0.0849)\end{array}$ & & $\begin{array}{c}0 \\
(0)\end{array}$ & $\begin{array}{l}-0.0272 \\
(0.0807)\end{array}$ \\
\hline Income per week [ $\$ 155-\$ 385]$ & & & $\begin{array}{l}-0.183^{* * *} \\
(0.0660)\end{array}$ & & $\begin{array}{c}0 \\
(0)\end{array}$ & $\begin{array}{c}-0.186 * * * \\
(0.0613)\end{array}$ \\
\hline Income per week $>\$ 675$ & & & $\begin{array}{l}0.311 * * * \\
(0.0625)\end{array}$ & & $\begin{array}{c}0 \\
(0)\end{array}$ & $\begin{array}{l}0.316 * * * \\
(0.0578)\end{array}$ \\
\hline $\begin{array}{l}\text { Labour Force status in former coun } \\
\text { (reference: NLF) }\end{array}$ & & & & & & \\
\hline Business owner & & & $\begin{array}{c}0.0925 \\
(0.0806)\end{array}$ & & $\begin{array}{c}0 \\
(0)\end{array}$ & $\begin{array}{c}0.0936 \\
(0.0723)\end{array}$ \\
\hline Wage earner & & & $\begin{array}{l}0.0919 * \\
(0.0512)\end{array}$ & & $\begin{array}{c}0 \\
(0)\end{array}$ & $\begin{array}{l}0.0947^{*} \\
(0.0488)\end{array}$ \\
\hline Unemployed & & & $\begin{array}{l}-0.0223 \\
(0.0949)\end{array}$ & & $\begin{array}{c}0 \\
(0)\end{array}$ & $\begin{array}{c}-0.0169 \\
(0.101)\end{array}$ \\
\hline Constant & $\begin{array}{c}-2.445^{* * *} \\
(0.208)\end{array}$ & & $\begin{array}{c}7.203 * * * \\
(0.189) \\
\end{array}$ & $\begin{array}{c}-2.458^{* * *} \\
(0.183)\end{array}$ & & $\begin{array}{c}6.758^{* * * *} \\
(0.632) \\
\end{array}$ \\
\hline $\begin{array}{l}\text { Observations } \\
\mathrm{Ll}\end{array}$ & $\begin{array}{l}14006 \\
-5104\end{array}$ & $\begin{array}{l}14006 \\
-5104\end{array}$ & $\begin{array}{c}2275 \\
-3006\end{array}$ & 13993 & 13993 & 13993 \\
\hline chi2 & 1612 & 1612 & & 514.6 & 514.6 & 514.6 \\
\hline Pseudo R2 & 0.178 & 0.178 & 0.190 & & & \\
\hline Lambda & & & & 0.166 & 0.166 & 0.166 \\
\hline Selambda & & & & 0.241 & 0.241 & 0.241 \\
\hline Sigma & & & & 0.921 & 0.921 & 0.921 \\
\hline Rho & & & & 0.181 & 0.181 & 0.181 \\
\hline
\end{tabular}

Robust standard errors in parentheses ${ }^{* * *} \mathrm{p}<0.01,{ }^{* *} \mathrm{p}<0.05$, ${ }^{*} \mathrm{p}<0.1$ 
Table 11: Difference in difference and cohort effects; conditional expectations

\begin{tabular}{lc}
\hline $\begin{array}{l}\text { Difference in difference and direct } \\
\text { cohort effect }\end{array}$ & Remittances \\
\hline Cohort & $0.509 * *$ \\
South America or Africa & 0.262 \\
South Europe & -0.0160 \\
Eastern Europe & 0.382 \\
Middle East & -0.141 \\
South East Asia & 0.0246 \\
North East Asia & -0.0980 \\
South Asia & 0.0742 \\
Business owner, self employed & $-0.692 *$ \\
Wage earner & -0.158 \\
Unemployed & 0.164 \\
Refugee visa & -0.0854 \\
Time spent in Australia & 0.0042 \\
& $(0.002923)$ \\
Time spent in Australia sq. & $-5.52 \mathrm{e}-06$ \\
& $4.15 \mathrm{e}-06$ \\
\hline
\end{tabular}

Table 12: Average levels of remittance by visa categories in 2000 AUD (with controls)

\begin{tabular}{lccccc}
\hline \multirow{2}{*}{ Visa categories } & \multicolumn{3}{c}{ cohort 1 } & \multicolumn{2}{c}{ cohort 2 } \\
& wave 1 & wave 2 & wave 3 & wave 4 & wave 5 \\
\hline \multirow{2}{*}{ Family } & $\mathbf{1 5 2 . 5 2}$ & $\mathbf{5 3 6 . 4 3}$ & $\mathbf{1 0 6 6 . 5}$ & $\mathbf{1 5 3 . 1 3}$ & $\mathbf{5 8 5 . 5 1}$ \\
& $(132.091)$ & $(368.169)$ & $(675.581)$ & $(154.934)$ & $(454.342)$ \\
Business & $\mathbf{2 3 2 . 3 5}$ & $\mathbf{7 3 1 . 2 4}$ & $\mathbf{1 2 8 8 . 1}$ & $\mathbf{1 7 6 . 1 8}$ & $\mathbf{6 9 7 . 3}$ \\
& $(205.505)$ & $(494.809)$ & $(669.848)$ & $(187.050)$ & $(600.001)$ \\
Independent & $\mathbf{3 3 6 . 8 9}$ & $\mathbf{1 0 9 0 . 1}$ & $\mathbf{2 0 5 8 . 2 8}$ & $\mathbf{3 2 1 . 9 5}$ & $\mathbf{1 0 2 4 . 3 6}$ \\
& $(285.509)$ & $(596.164)$ & $(883.364)$ & $(251.957)$ & $(596.219)$ \\
Refugee & $\mathbf{1 8 0 . 0 5}$ & $\mathbf{6 4 1 . 7 8}$ & $\mathbf{1 3 0 5 . 9}$ & $\mathbf{7 0 . 5 1}$ & $\mathbf{3 4 2 . 1 9}$ \\
& $(130.950)$ & $(411.263)$ & $(796.522)$ & $(95.318)$ & $(325.684)$ \\
\hline Total & $\mathbf{1 8 3 . 9 4}$ & $\mathbf{6 3 3 . 6 0}$ & $\mathbf{1 2 5 1 . 2 1}$ & $\mathbf{1 7 5 . 5 6}$ & $\mathbf{6 4 4 . 6 5}$ \\
& $(173.287)$ & $(454.027)$ & $(801.845)$ & $(188.88)$ & $(525.09)$ \\
\hline
\end{tabular}

Note: Standard deviation in parentheses 
Table 13: Average Levels of remittances by country of origin in 2000 AUD (with controls)

\begin{tabular}{|c|c|c|c|c|c|}
\hline \multirow[b]{2}{*}{ Country of origin } & \multicolumn{3}{|c|}{ cohort 1} & \multicolumn{2}{|c|}{ cohort 2} \\
\hline & wave 1 & wave 2 & wave 3 & wave 4 & wave 5 \\
\hline Oceania & $\begin{array}{c}72.65 \\
(57.14)\end{array}$ & $\begin{array}{c}\mathbf{3 3 0 . 5 4} \\
(192.11)\end{array}$ & $\begin{array}{c}\mathbf{6 4 5 . 1 8} \\
(374.78)\end{array}$ & $\begin{array}{c}\mathbf{1 5 3 . 9 0} \\
(123.63)\end{array}$ & $\begin{array}{c}\mathbf{5 6 4 . 2 4} \\
(332.13)\end{array}$ \\
\hline South Europe & $\begin{array}{c}\mathbf{1 4 7 . 3 8} \\
(119.08)\end{array}$ & $\begin{array}{c}\mathbf{5 8 0 . 3 3} \\
(406.63)\end{array}$ & $\begin{array}{l}\mathbf{1 2 5 5 . 4 1} \\
(804.40)\end{array}$ & $\begin{array}{c}\mathbf{8 2 . 7 4} \\
(87.68)\end{array}$ & $\begin{array}{c}394.66 \\
(309.60)\end{array}$ \\
\hline Western Europe & $\begin{array}{c}\mathbf{8 8 . 4 6} \\
(69.29)\end{array}$ & $\begin{array}{c}393.02 \\
(207.92)\end{array}$ & $\begin{array}{c}\mathbf{8 2 5 . 0 0} \\
(405.26)\end{array}$ & $\begin{array}{l}\mathbf{1 1 7 . 0 7} \\
(96.83)\end{array}$ & $\begin{array}{c}\mathbf{5 0 1 . 6 5} \\
(324.48)\end{array}$ \\
\hline Eastern E & $\begin{array}{c}\mathbf{8 7 . 7 5} \\
(92.84)\end{array}$ & $\begin{array}{c}391.23 \\
(315.71)\end{array}$ & $\begin{array}{c}\mathbf{8 2 1 . 8 1} \\
(558.86)\end{array}$ & $\begin{array}{c}227.51 \\
(210.93)\end{array}$ & $\begin{array}{c}\mathbf{8 4 0 . 0 6} \\
(577.40)\end{array}$ \\
\hline Middle East & $\begin{array}{c}\mathbf{1 3 7 . 0 3} \\
(100.35)\end{array}$ & $\begin{array}{c}\mathbf{5 4 1 . 4 0} \\
(369.78)\end{array}$ & $\begin{array}{c}\mathbf{1 1 2 5 . 7 5} \\
(736.55)\end{array}$ & $\begin{array}{c}\mathbf{9 0 . 4 7} \\
(96.25)\end{array}$ & $\begin{array}{c}348.25 \\
(270.59)\end{array}$ \\
\hline South East Asia & $\begin{array}{c}\mathbf{2 0 9 . 8 3} \\
(147.43)\end{array}$ & $\begin{array}{c}\mathbf{6 7 2 . 5 3} \\
(381.98)\end{array}$ & $\begin{array}{l}\mathbf{1 2 9 3 . 0 5} \\
(692.78)\end{array}$ & $\begin{array}{c}\mathbf{2 6 4 . 2 2} \\
(223.01)\end{array}$ & $\begin{array}{c}\mathbf{8 7 5 . 6 3} \\
\text { (543.84) }\end{array}$ \\
\hline North East Asia & $\begin{array}{c}\mathbf{2 0 6 . 0 4} \\
(215.21)\end{array}$ & $\begin{array}{c}\mathbf{6 8 5 . 7 3} \\
(529.63)\end{array}$ & $\begin{array}{l}\mathbf{1 3 3 5 . 1 9} \\
(884.86)\end{array}$ & $\begin{array}{c}\mathbf{1 3 1 . 1 3} \\
(146.39)\end{array}$ & $\begin{array}{c}\mathbf{5 4 5 . 5 2} \\
(465.07)\end{array}$ \\
\hline South Asia & $\begin{array}{l}337.32 \\
(44.28)\end{array}$ & $\begin{array}{c}\mathbf{9 9 7 . 5 0} \\
(0.00)\end{array}$ & $\begin{array}{c}\mathbf{1 8 5 1 . 6 2} \\
(34.28)\end{array}$ & $\begin{array}{c}\mathbf{3 0 0 . 5 7} \\
(155.22)\end{array}$ & $\begin{array}{c}\mathbf{1 1 1 6 . 3 2} \\
(107.51)\end{array}$ \\
\hline North America & $\begin{array}{c}\mathbf{2 0 2 . 8 4} \\
(261.55)\end{array}$ & $\begin{array}{c}\mathbf{6 9 6 . 9 9} \\
(603.92)\end{array}$ & $\begin{array}{l}\mathbf{1 2 7 0 . 3 2} \\
(987.86)\end{array}$ & $\begin{array}{c}155.19 \\
(240.45)\end{array}$ & $\begin{array}{c}\mathbf{6 6 4 . 9 5} \\
(670.15)\end{array}$ \\
\hline Great Britain, Ireland & $\begin{array}{c}\mathbf{5 3 . 4 6} \\
(67.44)\end{array}$ & $\begin{array}{l}436.33 \\
(68.48)\end{array}$ & $\begin{array}{c}949.74 \\
(0.00)\end{array}$ & $\begin{array}{l}32.09 \\
(0.00)\end{array}$ & \\
\hline Central and South America & $\begin{array}{c}\mathbf{1 3 8 . 6 1} \\
(119.92)\end{array}$ & $\begin{array}{c}\mathbf{5 4 0 . 5 2} \\
(374.79)\end{array}$ & $\begin{array}{l}\mathbf{1 0 8 4 . 3 5} \\
(676.39)\end{array}$ & $\begin{array}{c}\mathbf{2 5 0 . 9 0} \\
(215.18)\end{array}$ & $\begin{array}{c}\mathbf{9 6 2 . 3 3} \\
(608.44)\end{array}$ \\
\hline Africa & $\begin{array}{c}\mathbf{1 8 6 . 9 1} \\
(137.65)\end{array}$ & $\begin{array}{c}708.42 \\
(433.09)\end{array}$ & $\begin{array}{l}\mathbf{1 1 8 3 . 5 5} \\
(684.95)\end{array}$ & $\begin{array}{c}\mathbf{3 0 4 . 1 1} \\
(233.41)\end{array}$ & $\begin{array}{c}\mathbf{8 8 9 . 6 0} \\
\text { (529.84) }\end{array}$ \\
\hline Total & $\begin{array}{c}\mathbf{1 8 3 . 9 4} \\
(173.29)\end{array}$ & $\begin{array}{c}\mathbf{6 3 3 . 6 0} \\
(454.03)\end{array}$ & $\begin{array}{c}\mathbf{1 2 5 1 . 2 1} \\
(801.84)\end{array}$ & $\begin{array}{c}\mathbf{1 7 5 . 5 6} \\
(188.88)\end{array}$ & $\begin{array}{c}\mathbf{6 4 4 . 6 5} \\
(525.09)\end{array}$ \\
\hline
\end{tabular}

Note: Standard deviation in parentheses

Table 14: Average Levels of remittances by labour force status in 2000 AUD (with controls)

\begin{tabular}{lccccc}
\hline & & cohort 1 & \multicolumn{2}{c}{ cohort 2 } \\
Labour force status & wave 1 & wave 2 & wave 3 & wave 1 & wave 2 \\
\hline \multirow{2}{*}{ Business owner } & & & & & \\
& $\mathbf{2 0 8 . 0 5}$ & $\mathbf{6 7 1 . 7 9}$ & $\mathbf{1 3 3 6 . 4 3}$ & $\mathbf{5 4 . 1 2}$ & $\mathbf{2 4 2 . 4 2}$ \\
Wage earner & $(125.67)$ & $(318.36)$ & $(570.56)$ & $(32.98)$ & $(131.46)$ \\
& $\mathbf{4 0 5 . 2 7}$ & $\mathbf{1 0 9 9 . 2 4}$ & $\mathbf{1 9 3 6 . 3 1}$ & $\mathbf{3 6 6 . 4 7}$ & $\mathbf{1 1 2 6 . 5 6}$ \\
Other employed & $(233.60)$ & $(445.58)$ & $(688.01)$ & $(203.50)$ & $(455.34)$ \\
& $\mathbf{1 0 7 . 1 6}$ & $\mathbf{3 8 3 . 6 0}$ & $\mathbf{7 4 1 . 0 2}$ & $\mathbf{7 1 . 0 5}$ & $\mathbf{3 2 6 . 4 5}$ \\
Unemployed & $(56.25)$ & $(137.97)$ & $(235.32)$ & $(58.25)$ & $(170.40)$ \\
& $\mathbf{1 1 6 . 3 5}$ & $\mathbf{3 7 5 . 0 6}$ & $\mathbf{6 4 1 . 0 7}$ & $\mathbf{8 8 . 6 1}$ & $\mathbf{3 5 2 . 9 6}$ \\
Student & $(66.12)$ & $(153.92)$ & $(217.90)$ & $(58.28)$ & $(188.96)$ \\
& $\mathbf{1 3 6 . 0 4}$ & $\mathbf{4 3 0 . 7 8}$ & $\mathbf{8 5 3 . 3 2}$ & $\mathbf{7 6 . 7 2}$ & $\mathbf{3 2 6 . 4 8}$ \\
Not in LF & $(73.23)$ & $(171.08)$ & $(278.27)$ & $(53.76)$ & $(163.80)$ \\
& $\mathbf{1 0 8 . 8 8}$ & $\mathbf{3 3 6 . 1 5}$ & $\mathbf{6 2 2 . 3 3}$ & $\mathbf{7 0 . 8 5}$ & $\mathbf{2 5 8 . 4 8}$ \\
Total & $(72.48)$ & $(176.09)$ & $(285.12)$ & $(61.45)$ & $(140.18)$ \\
\hline
\end{tabular}

Note: Standard deviation in parentheses 
Fig1: Labour Force Status in Australia per wave of interview (population)

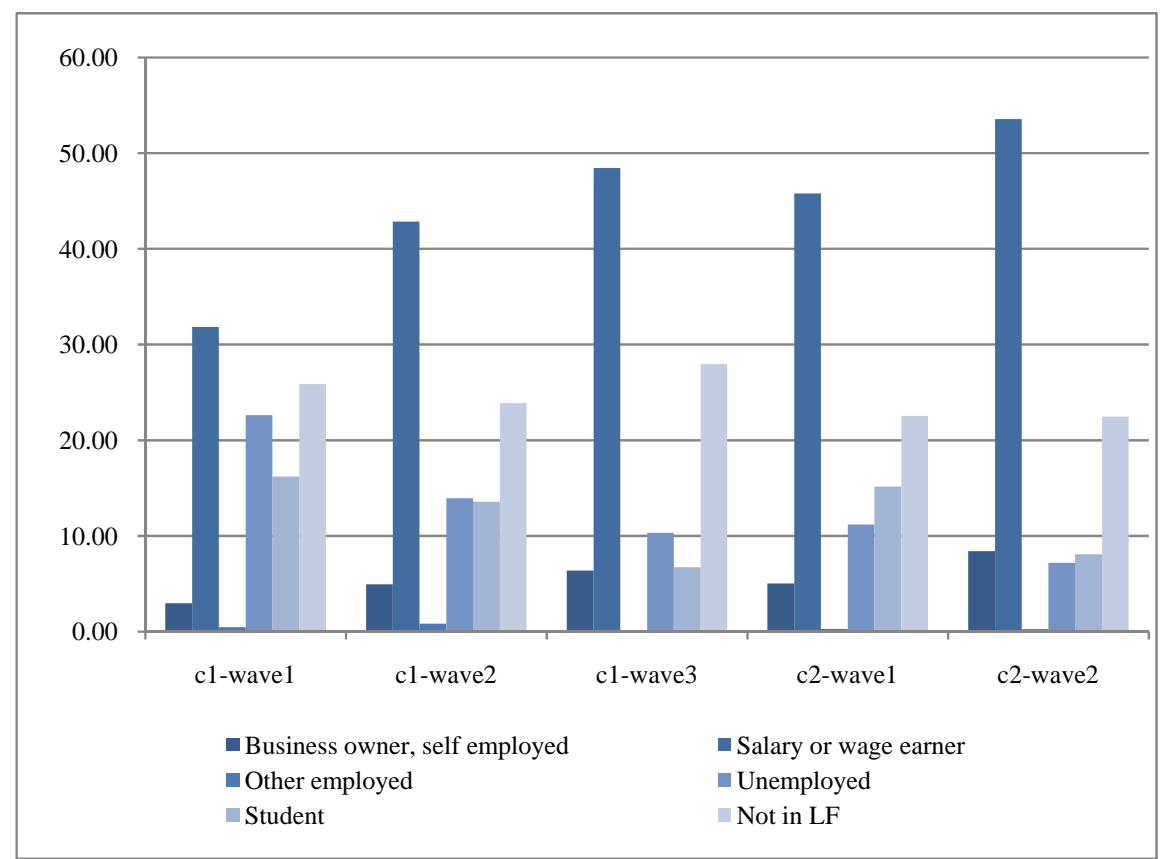

Fig 2: Labour Force Status in Australia across waves of interview: comparison per status (population)

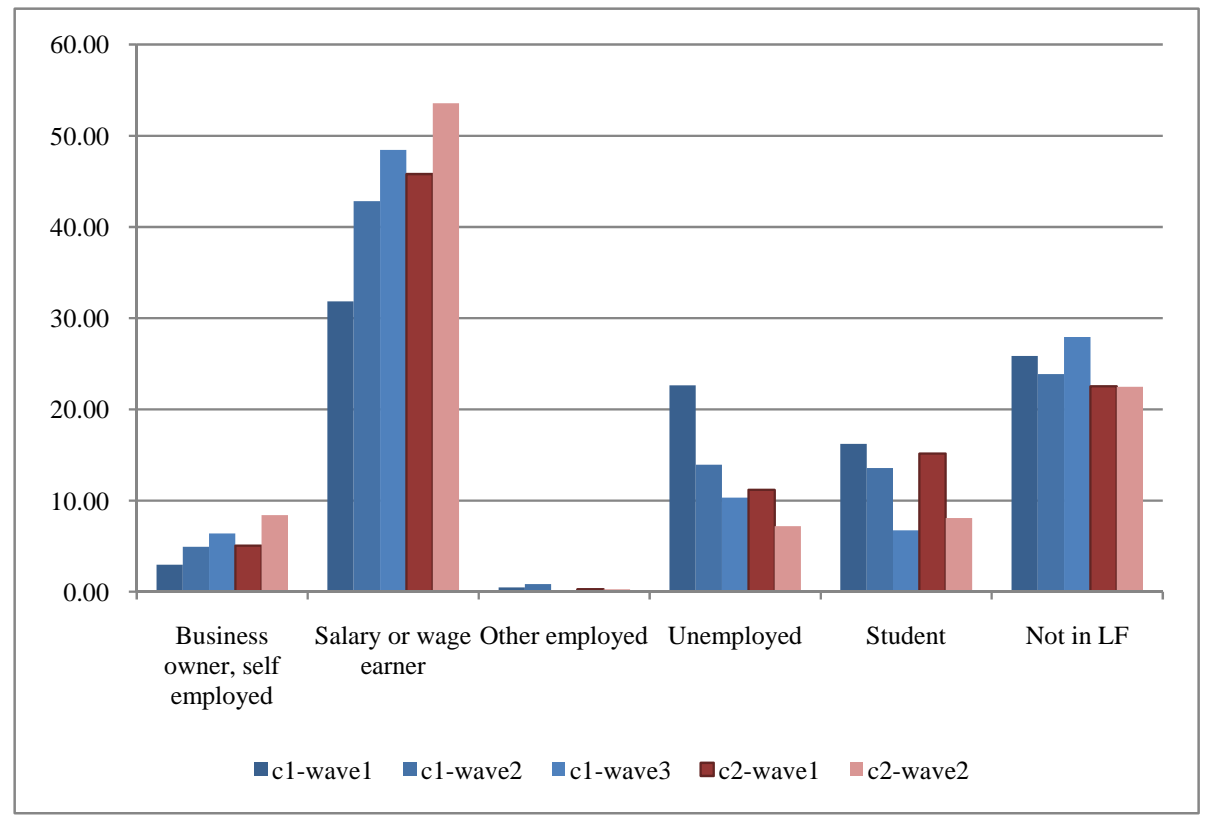

Fig 3: Remittances sent abroad according to time since arrival in Australia, in AUD (population) 


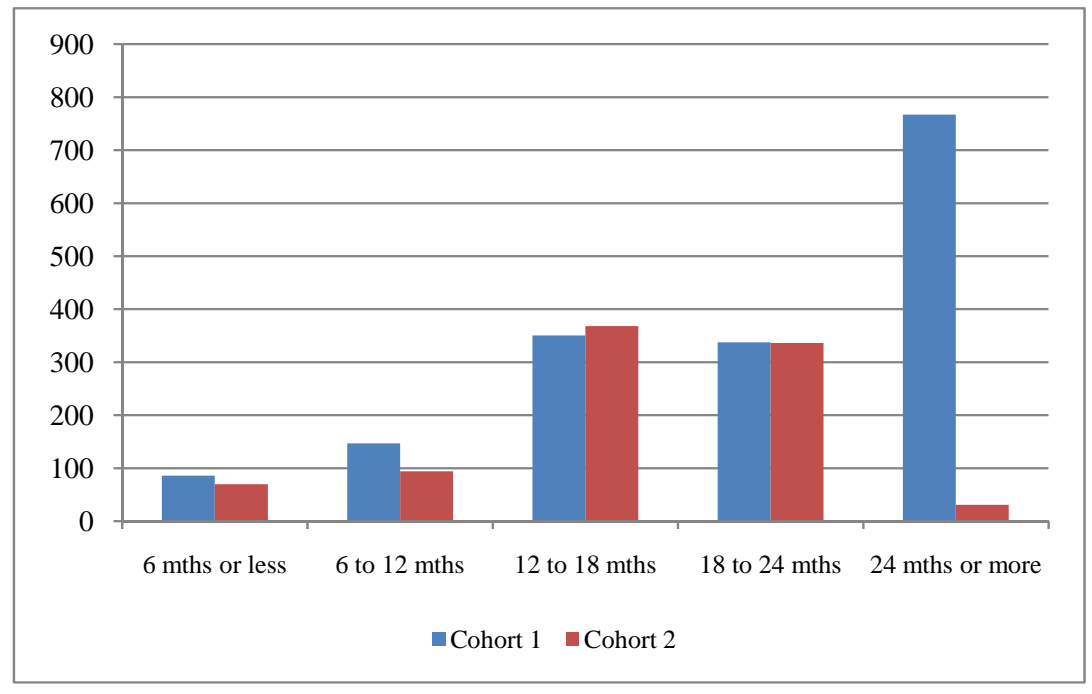

Fig 4: Estimated probability to remit according to time spent in Australia per cohort.

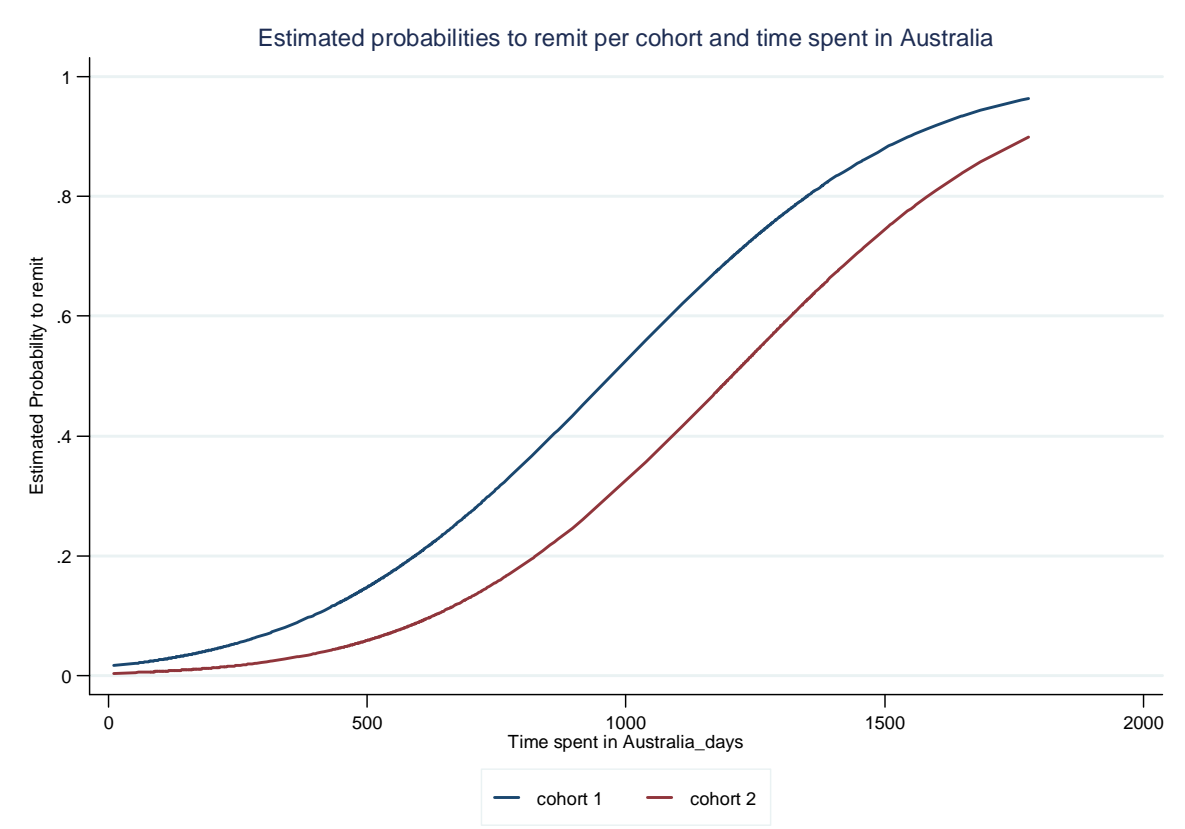


Fig 5: Estimated probability to remit according to time spent in Australia per country of origin, cohort 1.

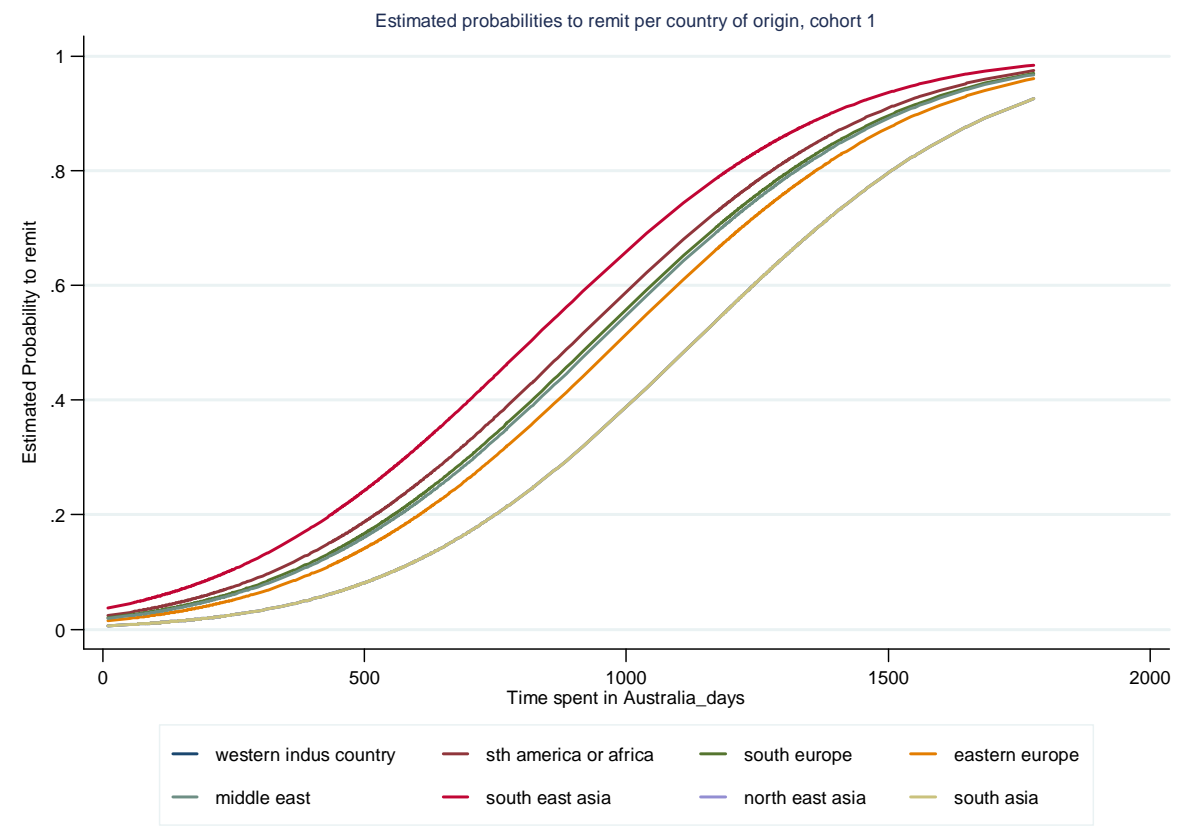

Fig 6: Estimated probability to remit according to time spent in Australia per country of origin, cohort 2.

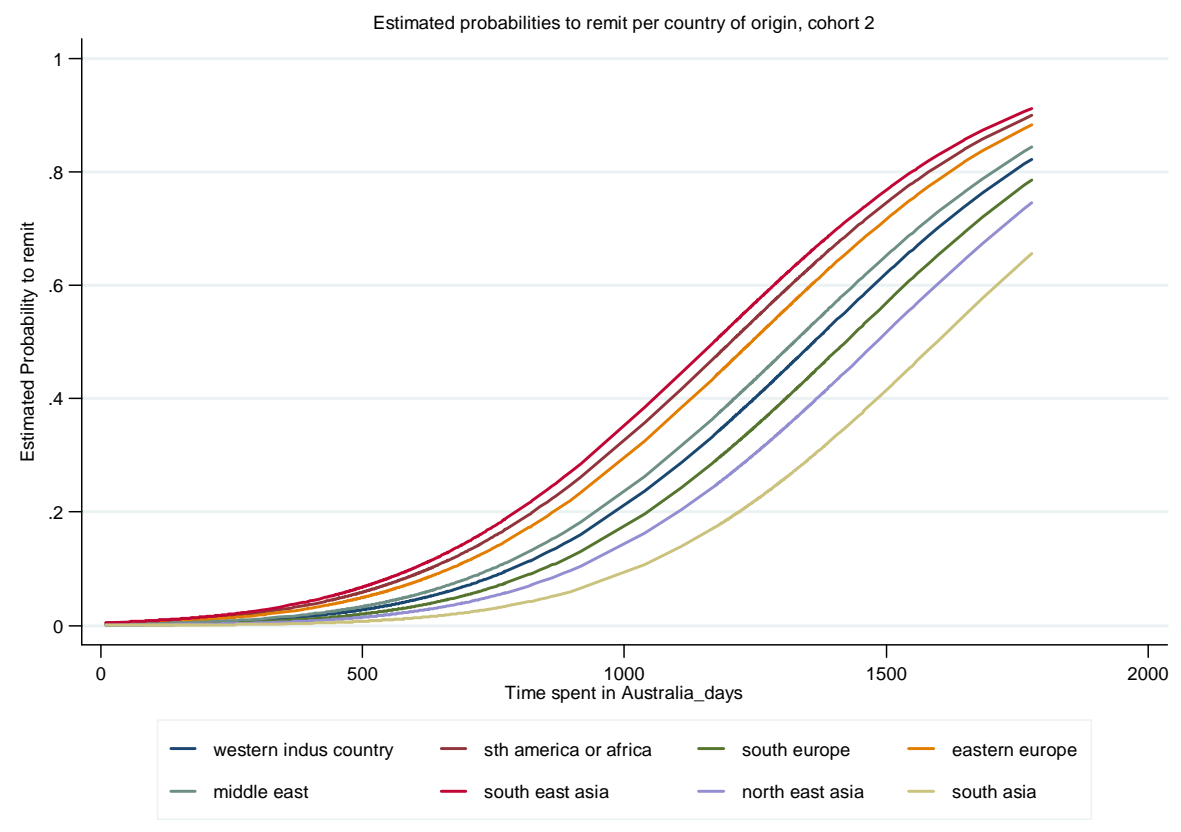

